\title{
Using the Water Quality Index (WQI), and the Synthetic Pollution Index (SPI) to Evaluate the Groundwater Quality for Drinking Purpose in Hailun, China
}

(Penggunaan Indeks Kualiti Air (WQI) dan Indeks Pencemaran Sintetik (SPI) untuk Menilai Kualiti Air Bawah Tanah untuk Tujuan Minuman di Hailun, China)

Tian Hui*, Du Jizhong, Sun Qifa, LiU Qiang, Kang Zhuang \& Jin HongtaO

\begin{abstract}
Due to the impact of human agricultural production, climate and environmental changes. The applicability of groundwater for drinking purposes has attracted widespread attention. In order to quantify the hydrochemical characteristics of groundwater in Hailun and evaluate its suitability for assessing water for drinking purposes, 77 shallow groundwater samples and 57 deep groundwater samples were collected and analyzed. The results show that deep groundwater in aquifers in the study area is weakly alkaline, while that in shallow is acidic. The abundance is in the order $\mathrm{HCO}_{3}^{->}$ $\mathrm{Cl}>\mathrm{SO}_{4}^{2-}$ for anions, and $\mathrm{Ca}^{2+}>\mathrm{Na}^{+}>\mathrm{Mg}^{2+}$ for cations. Groundwater chemical type were dominated by $\mathrm{HCO}_{3}-\mathrm{Ca}$, $\mathrm{HCO}_{3}-\mathrm{Ca} \bullet \mathrm{Mg}$, and $\mathrm{HCO}_{3}-\mathrm{Ca} \bullet \mathrm{Na}$. Correlation analysis (CA) and Durov diagram showed that rock weathering and dissolution, human activities, and the hydraulic connection between shallow and deep water are the main reasons affecting the chemical composition of water in Helen. The analysis of water samples based on the WQI model showed that about 23.37, 23.37, 32.46, 12.98, and 7.79\% of the shallow groundwater samples were excellent, good, poor, very poor, and unsuitable for drinking purposes, respectively, and that 61.40, 30.90, 5.26, 1.75, and 1.75\% of the deep groundwater samples were excellent, good, poor, very poor, and unsuitable for drinking purposes, respectively. The analysis of groundwater samples based on the SPI model showed that 92.98\% of the deep groundwater samples were suitable grade, while that $40.25 \%$ of the shallow groundwater samples were suitable grade. The spatial distribution maps of the WQI and SPI show that most of the deep groundwater resources in the study area are clean and suitable for drinking, despite the risks of the shallow groundwater in the north and southwest of the study area.
\end{abstract}

Keywords: China; groundwater quality assessment; hydrochemistry; SPI; WQI

\section{ABSTRAK}

Kesan daripada pengeluaran pertanian manusia, iklim dan persekitaran mengalami perubahan. Kebolehgunaan air bawah tanah untuk tujuan minuman telah menarik perhatian meluas. Untuk mengukur ciri hidrokimia air bawah tanah di Hailun dan menilai kesesuaian air untuk tujuan minuman, 77 sampel air bawah tanah yang cetek dan 57 sampel air bawah tanah yang dalam telah diambil dan dianalisis. Keputusan menunjukkan bahawa air bawah tanah yang dalam di akuifer di kawasan kajian adalah alkali yang lemah, manakala di kawasan yang cetek adalah berasid. Kebanyakannya adalah dalam turutan $\mathrm{HCO}_{3}^{->} \mathrm{Cl}^{-}>\mathrm{SO}_{4}{ }^{2-}$ untuk anion, dan $\mathrm{Ca}^{2+}>\mathrm{Na}^{+}>\mathrm{Mg}^{2+}$ untuk kation. Jenis kimia air bawah tanah didominasi oleh $\mathrm{HCO}_{3}-\mathrm{Ca}, \mathrm{HCO}_{3}-\mathrm{Ca} \bullet \mathrm{Mg}$ dan $\mathrm{HCO}_{3}-\mathrm{Ca} \bullet \mathrm{Na}$. Analisis korelasi (CA) dan rajah Durov menunjukkan bahawa luluhawa batuan dan pelarutan, aktiviti manusia, dan kaitan hidraulik antara air yang cetek dan dalam merupakan punca utama yang memberi kesan terhadap komposisi kimia air di Helen. Analisis sampel air berdasarkan model WQI menunjukkan bahawa 23.37, 23.37, 32.46, 12.98 dan 7.79\% daripada sampel air bawah tanah yang cetek masing-masing adalah sangat baik, baik, tidak baik, sangat tidak baik, dan tidak sesuai untuk tujuan minuman dan 61.40, 30.90, 5.26, 1.75 dan 1.75\% daripada sampel air bawah tanah yang dalam masing-masing adalah sangat baik, baik, tidak baik, sangat tidak baik, dan tidak sesuai untuk tujuan minuman. Analisis sampel air bawah tanah berdasarkan model SPI menunjukkan bahawa 92.98\% daripada sampel air bawah tanah yang dalam merupakan gred yang sesuai. Peta taburan ruang untuk WQI dan SPI menunjukkan bahawa kebanyakan daripada sumber air bawah tanah yang dalam di kawasan kajian adalah bersih dan sesuai untuk diminum, walaupun terdapat risiko daripada air bawah tanah yang cetek di utara dan barat daya kawasan kajian.

Kata kunci: China; hidrokimia; penilaian kualiti air bawah tanah; SPI; WQI 


\section{INTRODUCTION}

Water is one of the natural resources necessary for human survival and economic development (Boyd et al. 2019). However, in arid and semi-arid regions, uneven distribution of groundwater and surface water resources has become a contradiction that restricts living standards and economic development (Brhane et al. 2018). Understanding the relationship between groundwater and water demand for agricultural production is important for sustainable agricultural development (Zanotti et al. 2019). Groundwater has become the main source of fresh water for household, agricultural, and industrial uses due to its simple extraction and low cost (Hasan et al. 2017). In agricultural production areas, irrigation water, surface water and groundwater are closely linked, which has changed the hydrodynamic conditions and led to changes in groundwater hydrochemical conditions ( $\mathrm{Li}$ et al. 2019).

Therefore, understanding the chemical characteristics of groundwater and its influencing factors are critical to the protection and management of groundwater resources and the sustainable use of groundwater (Madlala et al. 2019). The Songnen Plain is one of the most important grain and grass production bases in China (Chen et al. 2019). Hailun is an important part of the northeast of the Songnen Plain and plays an important role in agricultural production. After 1995, grain production increased significantly, especially rice production. At the same time, with the increase of rice yield, groundwater irrigated area increased rapidly (Chen et al. 2019). The contradiction between the uneven distribution of water resources and the demand for irrigation water has become increasingly prominent, and farmers have to extract groundwater from aquifers for dryland irrigation. In the end, it will lead to a series of environmental geological problems, such as soil secondary salinization (Zhao et al. 2019), the core of depression (Sun et al. 2019; Zhao et al. 2010), wetland degradation (Li et al. 2019; Wu et al. 2019), and water quality deterioration (Tian et al. 2020a, 2019). However, the hydrogeochemical characteristics and drinking water quality of groundwater in agricultural irrigation areas (Hailun) are still not particularly clear. This may restrict the protection and proper use of groundwater resources, especially the drinking water safety issues of local residents.

In order to study the hydrochemical status and the quality of groundwater in Hailun, and quantitatively analyze the applicability of groundwater for drinking, 77 shallow groundwater samples and 57 deep groundwater samples were collected from Hailun between June and October in 2019. Using GIS and SPSS software, the hydrochemical properties and evolution of groundwater in the study area were characterized. The special purpose of this study was to: explore the hydrochemical characteristics of groundwater; understand the evolution of groundwater through Factor Analysis, and PCA analysis; and assess the applicability of groundwater as drinking water according to the parameters recommended in the WHO guidelines and using WQI and SPI models.

The results of the study help local governments strengthen management and governance in places where the groundwater environment is fragile, thereby effectively using groundwater resources in the river basin.

\section{STUDY AREA \\ STUDY AREA DESCRIPTION}

Helun is located in the middle of Heilongjiang Province in northeast China, adjacent to the northeast edge of the Songnen Plain. The study area is between $46^{\circ} 58^{\circ}$ and $47^{\circ}$ $52^{\prime} \mathrm{N}$, and $126^{\circ} 14$ 'and $127^{\circ} 45^{\prime} \mathrm{E}$, with an area of 4668 $\mathrm{km}^{2}$. The area is located in the mid-latitudes of the northern hemisphere and is a temperate continental semi-humid monsoon climate with four distinct seasons. The study area includes the urban area of Helen and 23 townships (Figure 1(b)). The total population of the study area is approximately 799,838 . The annual average temperature is $1-2{ }^{\circ} \mathrm{C}$, and the precipitation is between 550 and 600 $\mathrm{mm}$, which is mostly concentrated in June-August. The annual average evaporation is $1374 \mathrm{~mm}$, and the altitude of the study area is $190-400 \mathrm{~m}$ (Xing et al. 2019). The terrain slopes from southeast to the northwest. The study area contains four types of landforms: The hilly area in the northeast, the high plains in the east, the sloping plains in the middle, and the terraces and floodplains in the west (Li et al. 2019). The Hailun, Zhayin, and Sandaowulong Rivers flow through the area, indicating that surface water resources are abundant. The surface water is mainly used for farmland irrigation, especially rice farming. In the dry period, when the river water is dry and cannot meet the needs of agricultural production, large areas of groundwater are often extracted for irrigation.

\section{GEOLOGY AND HYDRO-GEOLOGY}

Under the control of neotectonic movements and geomorphological conditions, the Quaternary strata of the study area formed obvious differences between the northeast hilly areas, the eastern high plains, and the western plains (Figure 1(a)).

In the hilly area in the northeast, its internal structure has many sedimentary features, mainly Quaternary flood and alluvial layers. Its lithology is mainly silty clay which contains gravel locally and has a thickness of less than $5 \mathrm{~m}$. The Cretaceous Nenjiang Formation is below the Quaternary strata, and its lithology is siltstone, fine sandstone and shale, which are the main aquifers in this area. The aquifer is very thick and multi-layered, which is the main feature of this area. The groundwater level is buried at a depth of 5-15 m. The output of the Cretaceous confined aquifer is generally less than 300 tons/day (Tian et al. 2020b). 
(b)

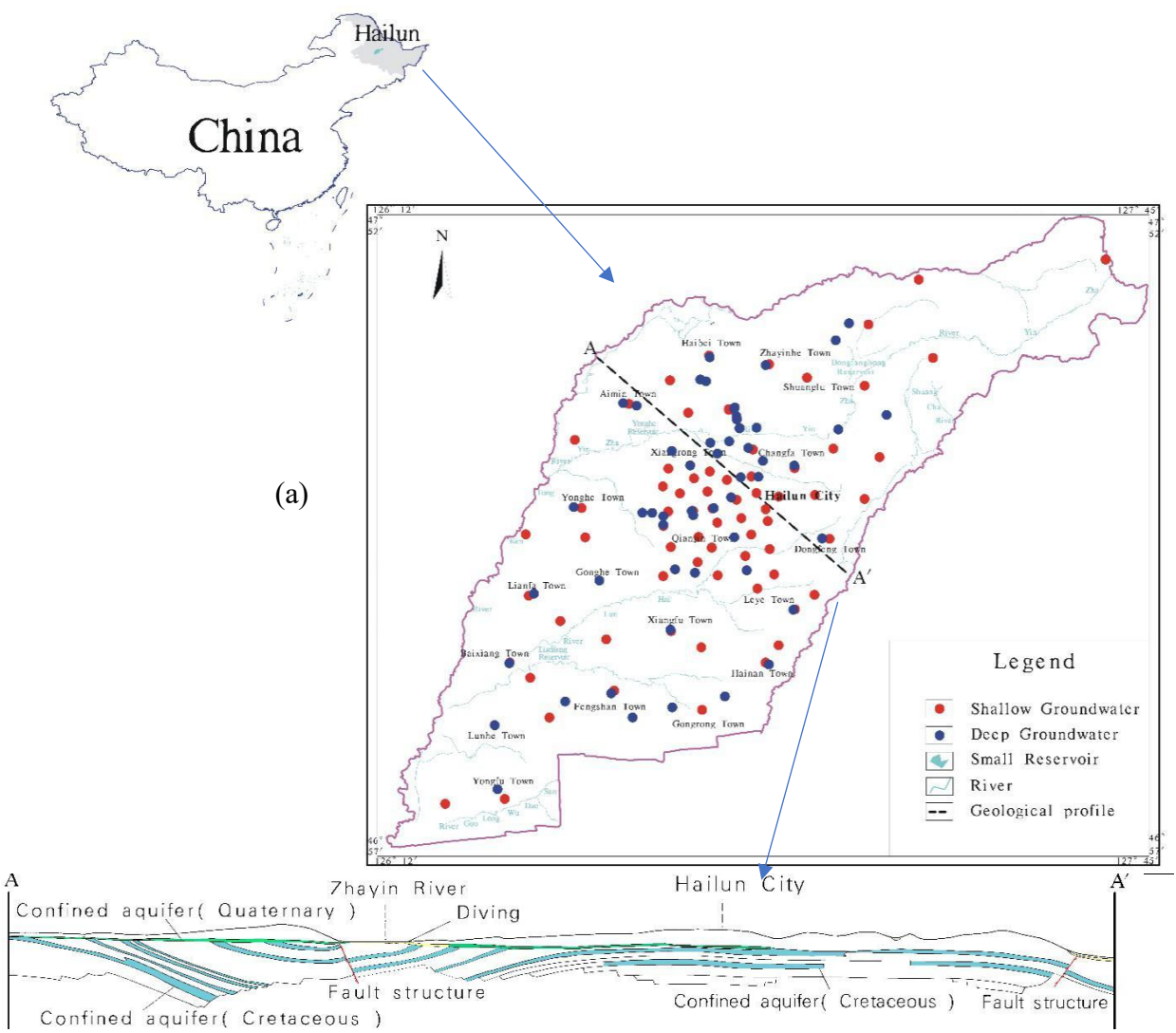

FIGURE 1. (a) Location and sampling sites of the study area and, (b) hydrogeological profile

In the eastern high plains, quaternary alluvial, flooding and lacustrine strata are widely distributed. The upper part is alluvial and lacustrine sedimentary strata. The lithology is mainly subclay, with vertical joints, but the porosity is small. The lower part is a lacustrine sedimentary stratum, with lithology of light yellow subclay, containing a large amount of iron-manganese nodules and humus, and the layer thickness is 15.0-36.0 $\mathrm{m}$. In this area, only Cretaceous confined water aquifers are developed, and the water output of aquifers is generally less than 100 tons/day (Niu et al. 2019).

In the western plains, Neogene alluvial, marsh sediments and Pleistocene alluvial are widely distributed. Quaternary strata are 7.8-30 m thick. The upper part of the formation is brownish yellow and yellow silty clay, and the lower part is gray-black muddy subclay. Cretaceous formations are mudstone and sandstone. The lithology of the aquifer is fine sand, gravel, sandstone, and fine sandstone. Quaternary diving, confined water and Cretaceous confined water, are the main mining layer in the area (Zhang et al. 2012). Under normal circumstances, the water output of a single well is 300-500 tons/day.

\section{MATERIALS AND METHODS}

\section{SAMPLING AND MEASUREMENTS}

According to the research plan, a total of 77 samples of shallow groundwater samples and 57 samples of deep groundwater samples were collected in two batches from June to October 2019. Deep groundwater samples were taken from the water supply wells in each town, and the depth was greater than 90 meters, which was confined water of the Cretaceous Nenjiang Formation. Shallow groundwater samples are taken from wells that are mainly used for water supply and irrigation in rural areas. Generally, the depth of the well is less than $40 \mathrm{~m}$, and its distribution is shown in Figure 1(a). The spatial distribution of sampling points is consistent with the distribution of water wells in each village, which can objectively reflect 
the characteristics of groundwater extraction in the study area. During the sampling process, each sampling well must be cleaned in accordance with the groundwater sampling guidelines, and the pumping time is greater than $10 \mathrm{~min}$. In the sampling process, the first step was to rinse the vial with well water three times, then filled with water and sealed. In the second step, the groundwater sample was stored in a $4{ }^{\circ} \mathrm{C}$ incubator. The third step was to return the sample to a qualified laboratory for testing. After the sampling was completed, groundwater samples were tested in the laboratory of the Shenyang Institute of Geology and Mineral Resources within three days.

The laboratory test index includes TDS, TH, Ca, Mg, $\mathrm{K}, \mathrm{Na}, \mathrm{Cl}, \mathrm{SO}_{4}, \mathrm{HCO}_{3}, \mathrm{NO}_{3}, \mathrm{NO}_{2}, \mathrm{Fe}, \mathrm{Mn}, \mathrm{Cr}$, and $\mathrm{Pb}$. TDS and $\mathrm{Ph}$ were measured in the field using a calibrated multi-parameter water quality analyzer (HACH-HQ40D). The concentration of $\mathrm{NO}_{2}$ and $\mathrm{NH}_{4}$ were obtained using gas phase molecular absorption spectrometry (GMA-3376). The concentrations of major anions $\left(\mathrm{Cl}, \mathrm{SO}_{4}\right.$, and $\left.\mathrm{NO}_{3}\right)$ were determined in the laboratory using ion chromatography (ICS-3000) and the concentration of major cations $(\mathrm{Ca}$, $\mathrm{Na}, \mathrm{K}$, and $\mathrm{Mg}$ ) was determined in the laboratory using plasma spectroscopy (ICP-6300).

\section{PRINCIPAL COMPONENT ANALYSES (PCA) AND CA}

PCA aims to use the idea of dimensionality reduction to transform multiple indicators into a few comprehensive indicators, where each principal component can reflect most of the information of the groundwater. The main steps in applying factor analysis are as follows: standardize the data samples, calculate the correlation matrix R of the samples, calculate the eigenvalue and eigenvectors of the correlation matrix R. Select variables with eigenvalues greater than 1, (4) determine the number of main factors according to the cumulative contribution rate required by the system. The cumulative contribution rate is chosen to be greater than $80 \%$, (5) calculate the loaded factor matrix A, (6) establish a factor model, and (7) based on the calculation results, analyze the relationship of factors in groundwater.

CA is one of the common methods used to evaluate the relationship between two variables. Using the established correlation coefficient matrix between variables, the potential connections between variables can been analyzed. If $0<\mathrm{R}<1$, it means that the two variables are positively correlated in linear. If $-1<\mathrm{R}<0$, it means that the two variables are negatively correlated in linear. In special cases, if $\mathrm{R}=0$, it means that there is no relationship between the two variables.

\section{DRINKING WQI}

WQI is a simple and useful approach for determining the overall quality of groundwater and its suitability for drinking purposes, and it has been widely used over the world (Wagh et al. 2019). The WQI was originally invented by Brown in 1970, and then improved by Backman in 1998. The World Health Organization (WHO) report (WHO 2008) emphasized that the WQI model helps to identify the impact of individual parameters of water quality and their combination on drinking water quality. Therefore, the WQI model can be used as a reliable tool for groundwater quality assessment (Sener et al. 2017). Specifically, the WQI model can be divided into four steps, including relative weight $\left(W_{i}\right)$ calculation, the quality rating $\left(q_{i}\right)$ calculation, the subindex of parameter $\left(\mathrm{SI}_{i}\right)$, and the result of WQI.

Step 1: The relative weight $\left(W_{\mathrm{i}}\right)$

$$
W_{\mathrm{i}}=\sum \frac{W_{i}}{\sum_{i=1}^{n} W_{i}}
$$

where $W_{i}$ is the relative weight of each parameter; and $n$ refers to the number of parameters. The weight $\left(w_{\mathrm{i}}\right)$ and relative weight $(\mathrm{Wi})$ of each chemical parameter are shown in Table 1 . As shown in Table 1, the weight $\left(w_{\mathrm{i}}\right)$ and relative weight $(\mathrm{Wi})$ of each parameter are according to WHO standards (Soleimani et al. 2018).

TABLE 1 . The weight $\left(w_{\mathrm{i}}\right)$ and relative weight $\left(W_{i}\right)$ of each chemical parameter

\begin{tabular}{lccccc}
\hline \multicolumn{1}{c}{ Parameters } & Units & Weight $\left(w_{\mathrm{i}}\right)$ & Relative weight $(W i)$ & $\begin{array}{c}\text { Limit } \\
\text { values }\end{array}$ & References \\
\hline $\mathrm{TDS}$ & $\mathrm{mg} / \mathrm{L}$ & 4 & 0.063 & 500 & (WHO 2018) \\
$\mathrm{TH}$ & $\mathrm{mg} / \mathrm{L}$ & 4 & 0.063 & 500 & (WHO 2018) \\
$\mathrm{PH}$ & - & 2 & 0.032 & $6.5-8.5$ & (WHO 2018) \\
$\mathrm{COD}$ & $\mathrm{mg} / \mathrm{L}$ & 5 & 0.079 & 10 & (WHO 2018) \\
$\mathrm{Na}$ & $\mathrm{mg} / \mathrm{L}$ & 4 & 0.063 & 200 & (WHO 2018) \\
$\mathrm{Ca}$ & $\mathrm{mg} / \mathrm{L}$ & 3 & 0.048 & 300 & (WHO 2018) \\
$\mathrm{Mg}$ & $\mathrm{mg} / \mathrm{L}$ & 3 & 0.048 & 30 & (WHO 2018) \\
$\mathrm{HCO}$ & $\mathrm{mg} / \mathrm{L}$ & 1 & 0.016 & 120 & (WHO 2018) \\
$\mathrm{Cl}$ & $\mathrm{mg} / \mathrm{L}$ & 4 & 0.063 & 250 & (WHO 2018)
\end{tabular}




\begin{tabular}{|c|c|c|c|c|c|}
\hline $\mathrm{SO}_{4}$ & $\mathrm{mg} / \mathrm{L}$ & 3 & 0.048 & 250 & (WHO 2018) \\
\hline $\mathrm{NO}_{3}$ & $\mathrm{mg} / \mathrm{L}$ & 5 & 0.079 & 50 & (WHO 2018) \\
\hline $\mathrm{NO}_{2}$ & $\mathrm{mg} / \mathrm{L}$ & 5 & 0.079 & 3 & (WHO 2018) \\
\hline $\mathrm{Fe}$ & $\mathrm{mg} / \mathrm{L}$ & 5 & 0.079 & 1 & $\begin{array}{l}\text { (Wooding et al. } \\
\text { 2017) }\end{array}$ \\
\hline $\mathrm{Mn}$ & $\mathrm{mg} / \mathrm{L}$ & 5 & 0.079 & 0.3 & $\begin{array}{l}\text { (Sener et al. } \\
\text { 2017) }\end{array}$ \\
\hline $\mathrm{Pb}$ & $\mathrm{mg} / \mathrm{L}$ & 5 & 0.079 & 0.01 & (WHO 2018) \\
\hline $\mathrm{Cr}$ & $\mathrm{mg} / \mathrm{L}$ & 5 & 0.079 & 0.05 & (WHO 2018) \\
\hline SUM & - & $\sum w_{\mathrm{i}}=63$ & $\sum w_{i}=1$ & - & \\
\hline
\end{tabular}

Step 2: The quality rating scale is the concentration of ions in the groundwater sample divided by the respective standard (WHO 2008 version) and multiplied by 100 .

$$
q_{i}=\left(\frac{c_{i}}{s_{i}}\right) \times 100
$$

where $C_{\mathrm{i}}$ is the concentration $(\mathrm{mg} / \mathrm{L})$ of ion chemical parameters in the sample; and $S_{\mathrm{i}}$ is the limit value $(\mathrm{mg} / \mathrm{L})$ of the corresponding chemical parameter in the guidelines issued by the World Health Organization (2008).

Step 3: The subindex of parameter $\left(\mathrm{SI}_{\mathrm{i}}\right)$

$$
\mathrm{SI}_{\mathrm{i}}=W_{i} \times q_{i}
$$

where $q i$ represents the rating based on concentration of its parameter; $W i$ is the relative weight, $\mathrm{SI}_{i}$ is the subindex of parameter (Kumar et al. 2017).

Step 4: The result of WQI for a single water sample

$$
\mathrm{WQI}=\sum_{i=1}^{n} \mathrm{SI}_{i}
$$

where $n$ is the number of parameters. According to WQI classification standards, water quality can be divided into five categories, as shown in Table 2.

\begin{tabular}{|c|c|}
\hline Range (WQI) & Type of groundwater \\
\hline$<50$ & Excellent water \\
\hline $50 \leq \mathrm{WQI}<100$ & Good water \\
\hline $100 \leq \mathrm{WQI}<200$ & Poor Water \\
\hline $200 \leq \mathrm{WQI}<300$ & Very poor water \\
\hline$\geq 300$ & $\begin{array}{l}\text { Unsuitable for drinking/Irrigation } \\
\text { purpose }\end{array}$ \\
\hline
\end{tabular}

TABLE 2. Water quality classification based on WQI classification standards (Khan \& Jhariya 2017)
THE SPI

The SPI model can be divided into three steps, including the constant of proportionality $\left(K_{i}\right)$, the weight coefficient $\left(W_{i}\right)$, and SPI. The derivation and calculation of SPI involves the following three steps (Solangi et al. 2018):

Step 1: The proportionality $\left(K_{i}\right)$

$$
K_{i}=\frac{1}{\sum_{i=1}^{n} \frac{1}{S_{i}}}
$$

Step2: The weight coefficient $\left(W_{i}\right)$

$$
W_{i}=\frac{K_{i}}{S_{i}}
$$

Step 3: The SPI

$$
\mathrm{SPI}=\sum_{i=1}^{n} \frac{C i}{S i} \times W i
$$

In equations (5), (6), and (7), $n$ is the number of water quality parameters for analysis, and $\mathrm{Si}$ is the threshold value of each parameter according to the WHO guidelines. According to SPI classification standards, water quality can be divided into five categories, as shown in Table 3.

TABLE 3. Water quality classification based on SPI classification standards (Gautam et al. 2015)

\begin{tabular}{lc}
\hline \multicolumn{1}{c}{ Range $(\mathrm{SPI})$} & Type of groundwater \\
\hline $\mathrm{SPI}<0.2$ & suitable \\
$0.2 \leq \mathrm{SPI}<0.5$ & slightly polluted \\
$0.5 \leq \mathrm{SPI}<1.0$ & moderately polluted \\
$1.0 \leq \mathrm{SPI}<3.0$ & highly polluted \\
$\mathrm{SPI} \geq 3.0$ & unsuitable for drinking purposes \\
\hline
\end{tabular}




\section{SOFTWARE}

This article uses SPSS statistical analysis software and GIS software. MapGIS6.7 software is the basic software platform for geographic information systems independently developed by China. MAPGIS6.7 is used to draw the location map of the study area, the distribution map of sampling points, the water chemistry type map, WQI and SPI evaluation map. SPSS19.0 is used for analysis and statistics of the component of anions and cations in water, and for principal component analysis.

\section{RESULTS AND DISCUSSION}

The groundwater chemistry is mainly affected by both natural and human factors. Natural factors include regional geological conditions, chemical composition of precipitation, hydrogeological conditions, and water-rock interactions (oxidation, reduction). Human factors include pesticide use, fertilizer use, groundwater extraction, groundwater recharge, and biological and microbial effects.

\section{PHYSICOCHEMICAL CHARACTERISTICS}

The results of statistical analysis of physical and chemical indicators of all groundwater samples are shown in Table 4. TDS and TH of groundwater in the shallow aquifer are observed in the ranges of 98.91-1920.13 and 60.27-1020.71 $\mathrm{mg} / \mathrm{L}$, respectively, and those in the deep aquifer are 39.78421.05 and 95.29-826.57 mg/L, respectively. According to WHO guidelines, the TDS and TH allowable value for drinking water is less than $500 \mathrm{mg} / \mathrm{L}$. The $\mathrm{pH}$ range of groundwater observed in shallow aquifers is 6.14-7.60, and the $\mathrm{pH}$ range observed in deep aquifers is 6.40 to 8.07 , which indicates that the shallow groundwater in the study area is weakly acidic, while the deep groundwater is weakly alkaline. According to WHO guidelines, the safe range of $\mathrm{pH}$ value for drinking water is 6.5-8.5. The COD in the water represents the degree of pollution of the water environment. The value of the COD for the shallow groundwater in the study area is $0.11-23.73 \mathrm{mg} / \mathrm{L}$, and for the deep groundwater in the study area is $0.43-3.88 \mathrm{mg} / \mathrm{L}$. Anions and cations show significant difference in deep and shallow groundwater. As shown in Table 4, the concentrations of $\mathrm{SO}_{4}^{2-}, \mathrm{HCO}_{3}^{-}$, and $\mathrm{Cl}^{-}$in deep groundwater are observed in the ranges of $0.13-72.24,25.75-660.80$, and $0.31-147.00 \mathrm{mg} / \mathrm{L}$, respectively, and those in shallow groundwater are in the ranges of $0.21-448.97,34.67-$ 809.00, and 0.13-317.38 mg/L, respectively. Both in shallow and deep groundwater, the average concentration of anions analyzed is in the order of $\mathrm{HCO}_{3}^{-}>\mathrm{Cl}^{-}>\mathrm{SO}_{4}{ }^{2-}$. The concentrations of $\mathrm{Ca}^{2+}, \mathrm{Mg}^{2+}$, and $\mathrm{Na}^{+}$in deep groundwater are observed in the ranges of 10.94-110.10, 2.03-35.09, and $3.57-206.00 \mathrm{mg} / \mathrm{L}$, respectively. While in shallow groundwater, the concentrations are observed in the ranges of 16.12-315.00, 3.75-70.37, and 4.90-215.97 mg/L, respectively. For both shallow and deep groundwater, the abundance of cations is in the following order: $\mathrm{Ca}^{2+}>\mathrm{Na}^{+}$ $>\mathrm{Mg}^{2+}$. It is worth noting that the concentrations of anions and cations in shallow groundwater are higher than those in deep groundwater.

According to studies, nitrate nitrogen in water has a greater harmful effect on humans and aquatic organisms. For example, when water with a nitrate content of greater than $10 \mathrm{mg} / \mathrm{L}$ is consumed over time, methemoglobinemia occurs. A blood methemoglobin content of $70 \mathrm{mg} / \mathrm{L}$ results in suffocation. In this study, the concentration of $\mathrm{NO}_{3}$ in shallow groundwater are in the range of $0.00-497.84 \mathrm{mg} / \mathrm{L}$ with the mean value of $63.40 \mathrm{mg} / \mathrm{L}$ (Figure 2(a)).

The concentration of $\mathrm{NO}_{3}$ in deep groundwater are in the range of $0.02-139.43 \mathrm{mg} / \mathrm{L}$ with the mean value of $9.81 \mathrm{mg} / \mathrm{L}$ (Figure 2(b)). The concentration of $\mathrm{NO}_{2}$ in shallow groundwater are in the range of $0.00-7.32$ $\mathrm{mg} / \mathrm{L}$ with the mean value of $0.28 \mathrm{mg} / \mathrm{L}$ (Figure 2(c)). The concentration of $\mathrm{NO}_{2}$ in groundwater are in the range of $0.00-4.85 \mathrm{mg} / \mathrm{L}$ with the mean value of $0.23 \mathrm{mg} / \mathrm{L}$ (Figure 2(d)). According to WHO guidelines, the allowable concentration for $\mathrm{NO}_{3}$ in water is $50 \mathrm{mg} / \mathrm{L}$, and the limited concentration for $\mathrm{NO}_{2}$ is $3 \mathrm{mg} / \mathrm{L}$. The increase of nitrate concentration is closely related to the use of chemical fertilizers and the infiltration of surface nitrogen (van Dijk et al. 2019).

In recent years, the concentrations of $\mathrm{Fe}$ and $\mathrm{Mn}$ in groundwater have received much attention and have been included in the evaluation standards for drinking water. In this study, $\mathrm{Fe}$ and $\mathrm{Mn}$ of groundwater in the shallow aquifer are observed in the ranges of 0.07-497.89 mg/L and $0.003-15.70 \mathrm{mg} / \mathrm{L}$ (Figure 2(e) and 2(g)), respectively, and those in the deep aquifer are $0.06-39.33 \mathrm{mg} / \mathrm{L}$ and 0.001-1.93 mg/L (Figure 2(f) and 2(h)), respectively. According to WHO guidelines, the allowable concentration for Fe in water is $1 \mathrm{mg} / \mathrm{L}$, and the limited concentration for $\mathrm{Mn}$ is $0.3 \mathrm{mg} / \mathrm{L}$. The high concentrations of Fe and $\mathrm{Mn}$ in groundwater indicate high concentrations of $\mathrm{Fe}$ and $\mathrm{Mn}$ in depositional environment in the aquifer throughout the study area (Rotiroti et al. 2013).

High levels of heavy metals in drinking water can cause poisoning, carcinogenesis and various diseases (Ravindra et al. 2019). In this study, $\mathrm{Cr}$ and $\mathrm{Pb}$ of groundwater in the shallow aquifer are observed in the ranges of $0.0007-0.0094$ and $0.00-0.0838 \mathrm{mg} / \mathrm{L}$ (Figure 2(i) and 2(1)), respectively, and those in the deep aquifer are $0.00-0.0046$ and $0.00-0.0013 \mathrm{mg} / \mathrm{L}$ (Figure 2(j) and $2(\mathrm{~m}))$, respectively. According to WHO guidelines, the allowable concentration for $\mathrm{Cr}$ in water is $0.01 \mathrm{mg} / \mathrm{L}$, and the limited concentration for $\mathrm{Pb}$ is $0.05 \mathrm{mg} / \mathrm{L}$. In summary, the concentration of $\mathrm{Cr}$ and $\mathrm{Pb}$ is within the limited range, which indicates that the content of heavy metals in groundwater is low. 
TABLE 4. Statistics of the measured parameters for groundwater samples

\begin{tabular}{|c|c|c|c|c|c|c|c|}
\hline & Parameters & Unit & Minimum & Maximum & Mean & SD & $\mathrm{CV}(\%)$ \\
\hline \multirow{16}{*}{$\begin{array}{l}3 \\
0 \\
3 \\
\frac{3}{\bar{J}} \\
\frac{\pi}{\pi}\end{array}$} & $\mathrm{TH}$ & $\mathrm{mg} / \mathrm{L}$ & 60.27 & 1020.71 & 373.23 & 229.84 & 61.58 \\
\hline & TDS & $\mathrm{mg} / \mathrm{L}$ & 98.91 & 1920.13 & 561.81 & 396.26 & 70.53 \\
\hline & $\mathrm{pH}$ & - & 6.14 & 7.60 & 6.93 & 0.35 & 5.07 \\
\hline & COD & $\mathrm{mg} / \mathrm{L}$ & 0.11 & 23.73 & 3.11 & 3.74 & 120.21 \\
\hline & $\mathrm{Ca}$ & $\mathrm{mg} / \mathrm{L}$ & 16.12 & 315.00 & 106.01 & 70.65 & 66.64 \\
\hline & $\mathrm{Mg}$ & $\mathrm{mg} / \mathrm{L}$ & 3.75 & 70.37 & 23.72 & 14.15 & 59.65 \\
\hline & $\mathrm{Na}$ & $\mathrm{mg} / \mathrm{L}$ & 4.90 & 215.97 & 35.23 & 37.26 & 105.75 \\
\hline & $\mathrm{Cl}$ & $\mathrm{mg} / \mathrm{L}$ & 0.13 & 317.38 & 87.01 & 89.58 & 102.95 \\
\hline & $\mathrm{SO}_{4}$ & $\mathrm{mg} / \mathrm{L}$ & 0.21 & 448.97 & 62.97 & 80.78 & 128.29 \\
\hline & $\mathrm{HCO}_{3}$ & $\mathrm{mg} / \mathrm{L}$ & 34.67 & 809.00 & 249.79 & 126.41 & 50.61 \\
\hline & $\mathrm{NO}_{3}$ & $\mathrm{mg} / \mathrm{L}$ & 0.0000 & 497.84 & 63.40 & 107.42 & 169.43 \\
\hline & $\mathrm{NO}_{2}$ & $\mathrm{mg} / \mathrm{L}$ & 0.0000 & 7.32 & 0.28 & 0.91 & 324.28 \\
\hline & $\mathrm{Fe}$ & $\mathrm{mg} / \mathrm{L}$ & 0.0706 & 497.89 & 56.67 & 108.93 & 192.21 \\
\hline & $\mathrm{Mn}$ & $\mathrm{mg} / \mathrm{L}$ & 0.0038 & 15.70 & 1.33 & 2.04 & 153.70 \\
\hline & $\mathrm{Cr}$ & $\mathrm{mg} / \mathrm{L}$ & 0.0007 & 0.00940 & 0.00364 & 0.00205 & 56.36 \\
\hline & $\mathrm{Pb}$ & $\mathrm{mg} / \mathrm{L}$ & 0.0000 & 0.08388 & 0.00175 & 0.00959 & 548.54 \\
\hline \multirow{16}{*}{ 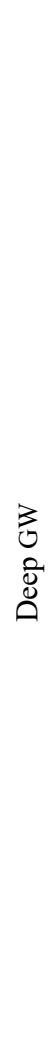 } & $\mathrm{TH}$ & $\mathrm{mg} / \mathrm{L}$ & 95.29 & 826.57 & 332.05 & 123.99 & 37.34 \\
\hline & TDS & $\mathrm{mg} / \mathrm{L}$ & 39.78 & 421.05 & 200.23 & 80.90 & 40.40 \\
\hline & $\mathrm{pH}$ & - & 6.40 & 8.07 & 7.50 & 0.35 & 4.71 \\
\hline & COD & $\mathrm{mg} / \mathrm{L}$ & 0.43 & 3.88 & 1.50 & 0.71 & 47.41 \\
\hline & $\mathrm{Ca}$ & $\mathrm{mg} / \mathrm{L}$ & 10.94 & 110.10 & 52.69 & 22.00 & 41.75 \\
\hline & $\mathrm{Mg}$ & $\mathrm{mg} / \mathrm{L}$ & 2.03 & 35.09 & 15.01 & 7.54 & 50.23 \\
\hline & $\mathrm{Na}$ & $\mathrm{mg} / \mathrm{L}$ & 3.57 & 206.00 & 42.80 & 42.06 & 98.26 \\
\hline & $\mathrm{Cl}$ & $\mathrm{mg} / \mathrm{L}$ & 0.31 & 147.00 & 20.77 & 28.28 & 136.14 \\
\hline & $\mathrm{SO}_{4}$ & $\mathrm{mg} / \mathrm{L}$ & 0.13 & 72.24 & 13.66 & 14.29 & 104.58 \\
\hline & $\mathrm{HCO}_{3}$ & $\mathrm{mg} / \mathrm{L}$ & 25.75 & 660.80 & 284.78 & 112.22 & 39.40 \\
\hline & $\mathrm{NO}_{3}$ & $\mathrm{mg} / \mathrm{L}$ & 0.0246 & 139.43 & 9.81 & 23.05 & 234.92 \\
\hline & $\mathrm{NO}_{2}$ & $\mathrm{mg} / \mathrm{L}$ & 0.0000 & 4.85 & 0.23 & 0.70 & 311.03 \\
\hline & $\mathrm{Fe}$ & $\mathrm{mg} / \mathrm{L}$ & 0.0640 & 39.33 & 2.54 & 6.83 & 268.93 \\
\hline & $\mathrm{Mn}$ & $\mathrm{mg} / \mathrm{L}$ & 0.0018 & 1.93 & 0.45 & 0.48 & 105.93 \\
\hline & $\mathrm{Cr}$ & $\mathrm{mg} / \mathrm{L}$ & 0.0000 & 0.0046 & 0.0006 & 0.0011 & 179.50 \\
\hline & $\mathrm{Pb}$ & $\mathrm{mg} / \mathrm{L}$ & 0.0000 & 0.0013 & 0.0002 & 0.0003 & 136.22 \\
\hline
\end{tabular}

$\mathrm{CV}=$ Coefficient of variation, $\mathrm{SD}=$ Standard deviation 


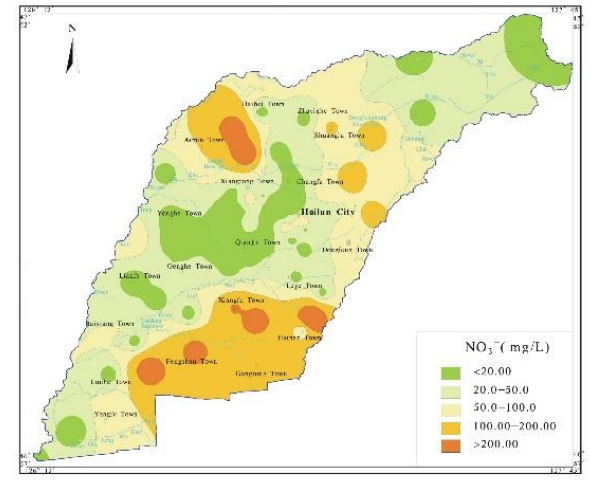

(a)

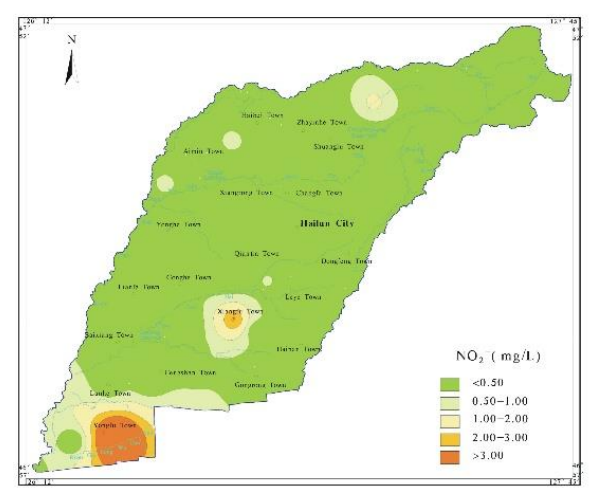

(c)

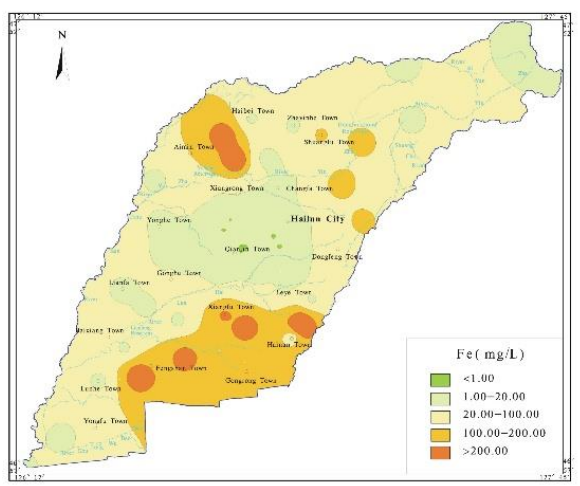

(e)

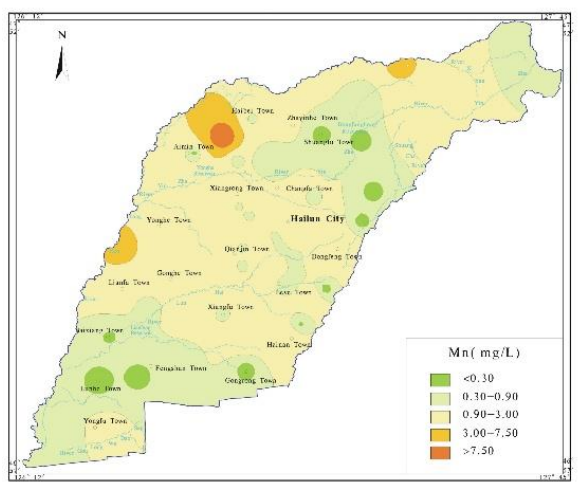

(g)

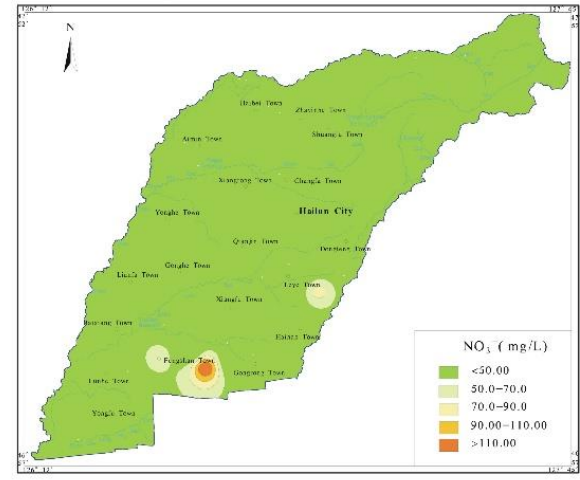

(b)

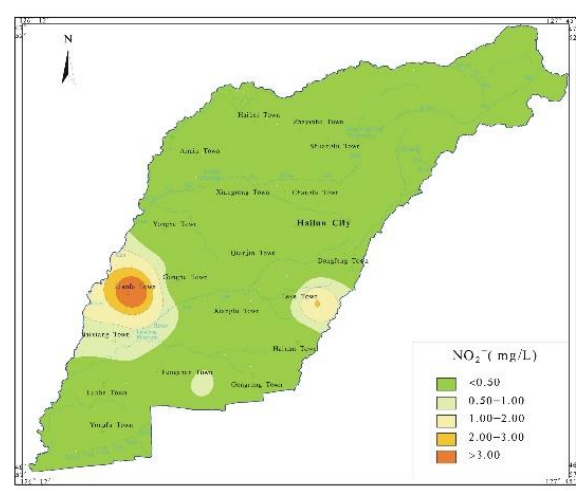

(d)

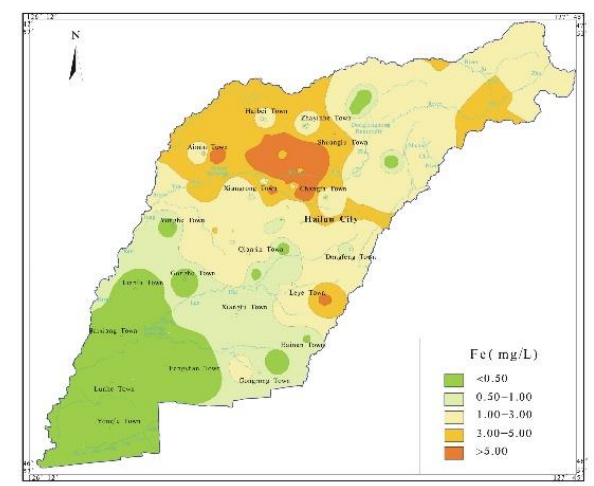

(f)

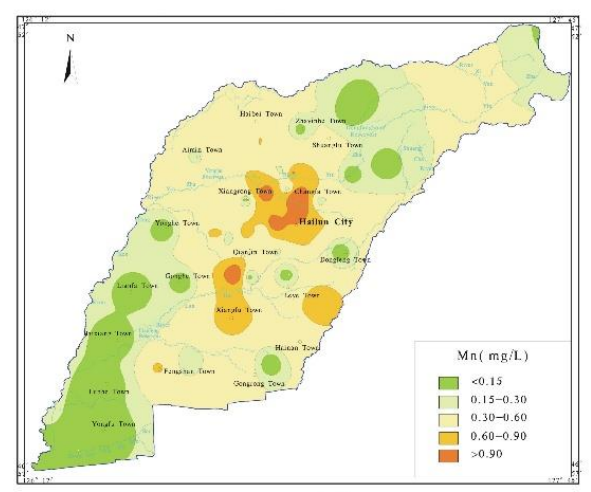

(h) 


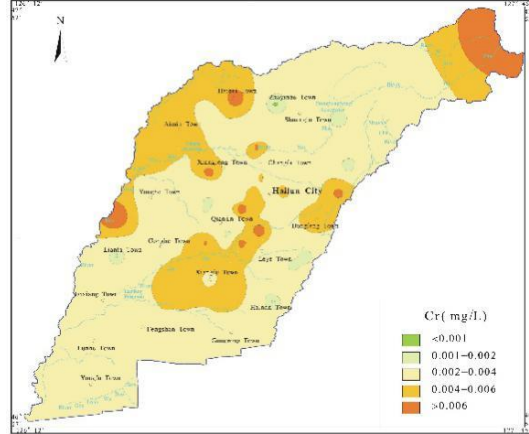

(i)

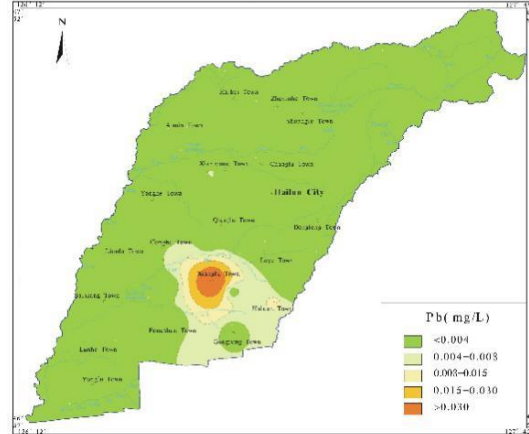

(1)

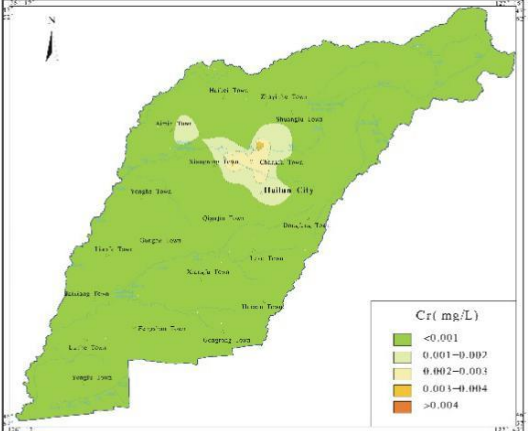

(j)

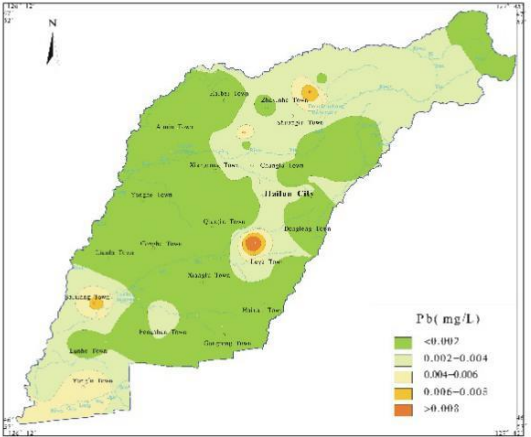

$(\mathrm{m})$

FIGURE 2. (a) concentration of $\mathrm{NO}_{3}$ in shallow groundwater, (b) concentration of $\mathrm{NO}_{3}$ in deep groundwater, (c) concentration of $\mathrm{NO}_{2}$ in shallow groundwater, (d) concentration of $\mathrm{NO}_{2}$ in groundwater, (e) concentration of $\mathrm{Fe}$ in groundwater in the shallow aquifer, (f) concentration of $\mathrm{Fe}$ in the deep aquifer, (g) concentration of $\mathrm{Mn}$ in groundwater in the shallow aquifer, (h) concentration of $\mathrm{Mn}$ in the deep aquifer, (i) concentration of $\mathrm{Cr}$ of groundwater in the shallow aquifer, (j) concentration of $\mathrm{Cr}$ in the deep aquifer, (1) concentration of $\mathrm{Pb}$ of groundwater in the shallow aquifer concentration of $\mathrm{Cr}$ and $\mathrm{Pb}$ of groundwater in the shallow aquifer and $(\mathrm{m})$ concentration of $\mathrm{Pb}$ in the deep aquifer

THE DUROV DIAGRAM AND GROUNDWATER HYDROCHEMICAL TYPES

In order to accurately reflect and describe the groundwater chemistry in the study area, the Durov chart was drawn using MapGIS 6.7 software (Karunanidhi et al. 2020). As shown in Figure 3, chemical differences between shallow groundwater and deep groundwater are also reflected. The shallow groundwater samples had a larger variated range of TDS content varying from $100-1900 \mathrm{mg} / \mathrm{L}$, while the TDS of deep groundwater are less than $550 \mathrm{mg} / \mathrm{L}$. The

\section{Durov Diagram}

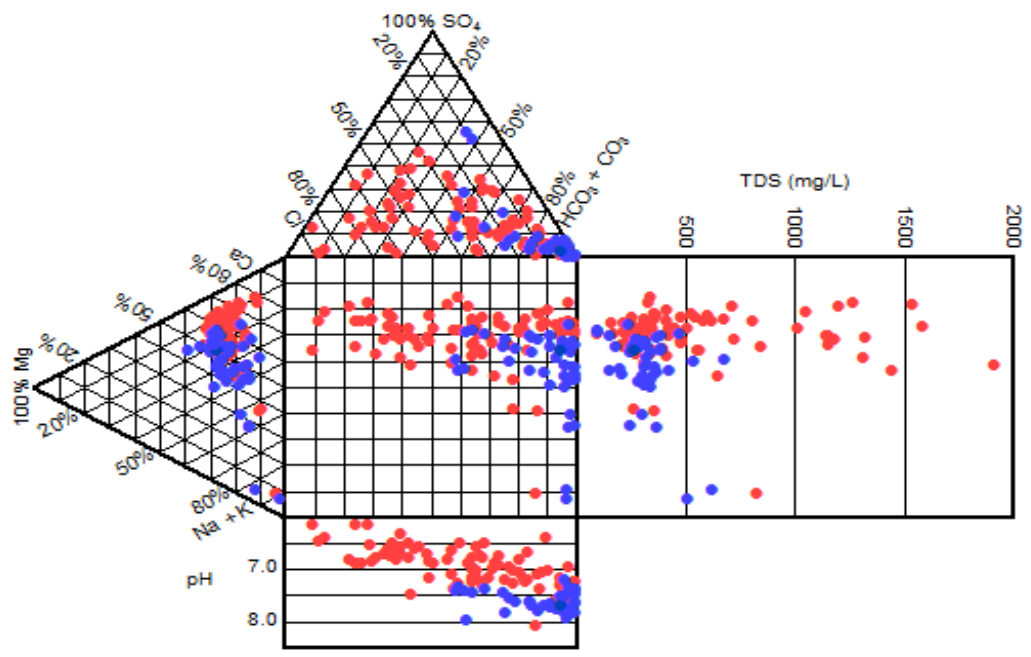

FIGURE 3. Durov diagram of groundwater samples (red-shallow GW; blue-deep GW) 
diagram also shows that $\mathrm{Ca}$ and $\mathrm{Na}$ are the main cations in groundwater, and $\mathrm{HCO}_{3}$ and $\mathrm{Cl}$ are the main anions. The concentration of $\mathrm{Na}$ ion is closely related to evaporation and ion exchange of diving. According to the Durov chart, the groundwater in the deep and shallow aquifers in the Helen area is mainly controlled by $\mathrm{HCO}_{3}-\mathrm{Ca}, \mathrm{HCO}_{3}-\mathrm{Ca}$ $\mathrm{Mg}$, and $\mathrm{HCO}_{3}-\mathrm{Ca} \cdot \mathrm{Na}$ types.

\section{PCA AND CA}

PCA and CA can help identify relationships and sources of ions in groundwater. Three principal components with characteristic root values greater than 1 in shallow groundwater were extracted and analyzed (Figure 4(a), Table 5). Factor 1 , with a variance of about $47.93 \%$, includes TDS, TH, $\mathrm{Na}^{+}, \mathrm{Ca}^{2+}, \mathrm{Mg}^{2+}, \mathrm{SO}_{4}^{2-}$, and $\mathrm{Cl}$, suggesting that TDS and TH content of shallow groundwater are mainly affected by $\mathrm{Ca}^{2+}$ and $\mathrm{Mg}^{2+}$ in the study area (Ravikumar $\&$ Somashekar 2017). The high correlation between $\mathrm{Ca}^{2+}$, $\mathrm{Mg}^{2+}$ and $\mathrm{Na}^{+}$indicates that a strong exchange adsorption occurs between $\mathrm{Ca}^{2+}, \mathrm{Mg}^{2+}$ and $\mathrm{Na}^{+}$in groundwater. Factor 2 controls $17.28 \%$ of the shallow groundwater chemistry parameters, including $\mathrm{pH}$, and $\mathrm{HCO}_{3}^{-}$. The high correlation

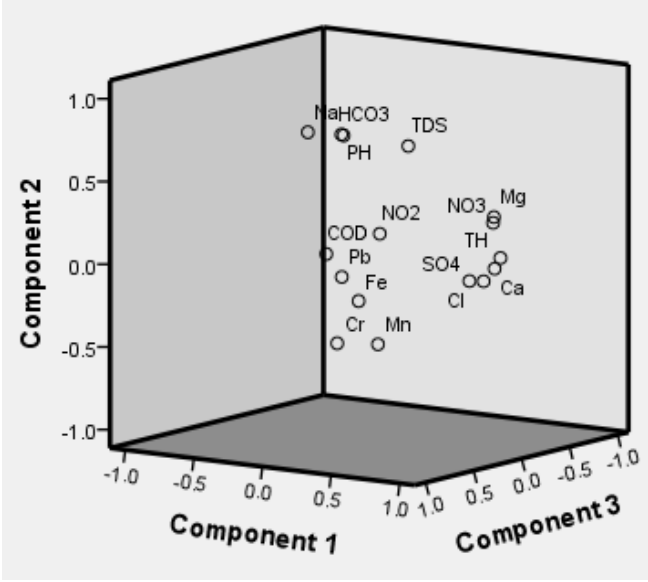

(a)

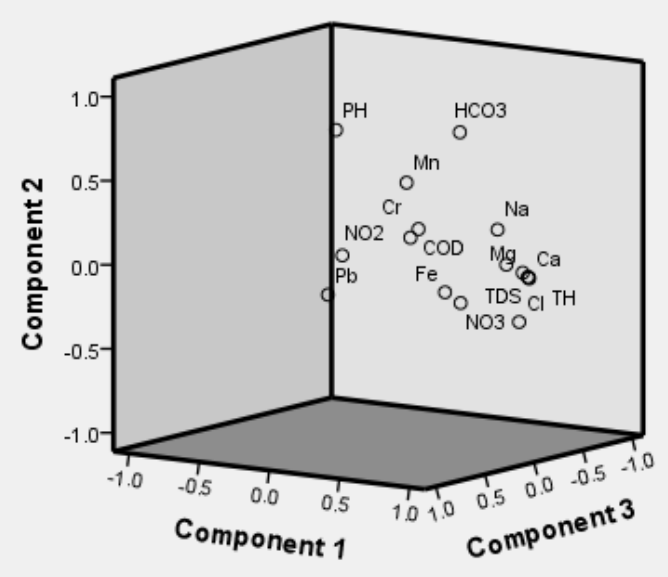

(b)

FIGURE 4. PCA plot of the (a) deep, and (b) shallow groundwater

between $\mathrm{HCO}_{3}^{-}$, and $\mathrm{pH}$ indicates that shallow groundwater is weakly acidic and is mainly caused by bicarbonate. Factor 3 contains $16.89 \%$ of all variables, including $\mathrm{NO}_{2}{ }^{-}$and $\mathrm{P}_{b}$, suggesting the amount of $\mathrm{NO}_{2}^{-}$in groundwater is highly correlated with the content of $\mathrm{Pb}$ (Dippong et al. 2019). The high levels of $\mathrm{NO}_{2}{ }^{-}$and $\mathrm{P}_{\mathrm{b}}$ are closely related to human activities, especially the use of chemical fertilizers, domestic sewage irrigation, and landfill leakage. Factors 3 also suggest that shallow groundwater in some areas has been contaminated with agricultural chemical fertilizers, indicating that groundwater recharged by agricultural irrigation water is the main cause of groundwater pollution (Abbasnia et al. 2018).

Similarly, three main components with characteristic root values greater than 1 in deep groundwater were extracted and analyzed (Figure 4(b), Table 5). Factor 1, with a variance of about $35.96 \%$, includes TDS, TH, $\mathrm{Ca}^{2+}$, $\mathrm{Mg}^{2+}, \mathrm{NO}_{3}^{-}$, and $\mathrm{Cl}^{-}$, suggesting that TDS and TH content of groundwater are mainly affected by $\mathrm{Ca}^{2+}$ and $\mathrm{Mg}^{2+}$ ions in the study area, and that is consistent with shallow groundwater. The high correlation between $\mathrm{Cl}^{-}$, and $\mathrm{NO}_{3}^{-}$ indicates that their sources are consistent and are closely related to the use of fertilizers. It proves that agricultural production activities have an impact on shallow and deep groundwater, and also shows that there is a close hydraulic connection between shallow groundwater and deep groundwater (Misaghi et al. 2017). Factor 2 controls $27.57 \%$ of the water chemistry parameters, including $\mathrm{Na}^{+}$, and $\mathrm{HCO}_{3}^{-}$. The high correlation between $\mathrm{HCO}_{3}^{-}$, and $\mathrm{Na}^{+}$indicates that their sources are consistent and are closely related to the rock weathering and dissolution (Gastmans et al. 2017). Factor 3 contains $18.16 \%$ of all variables (including $\mathrm{Cr}$ and $\mathrm{Mn}$ ), indicating that the content of $\mathrm{Cr}$ in groundwater is consistent with the content of $\mathrm{Mn}$, both of which come from the dissolution of $\mathrm{Mn}$ and $\mathrm{Cr}$ in water in the aquifer (Hausladen et al. 2018). 
TABLE 5. Groundwater physical and chemical parameter correlation matrix

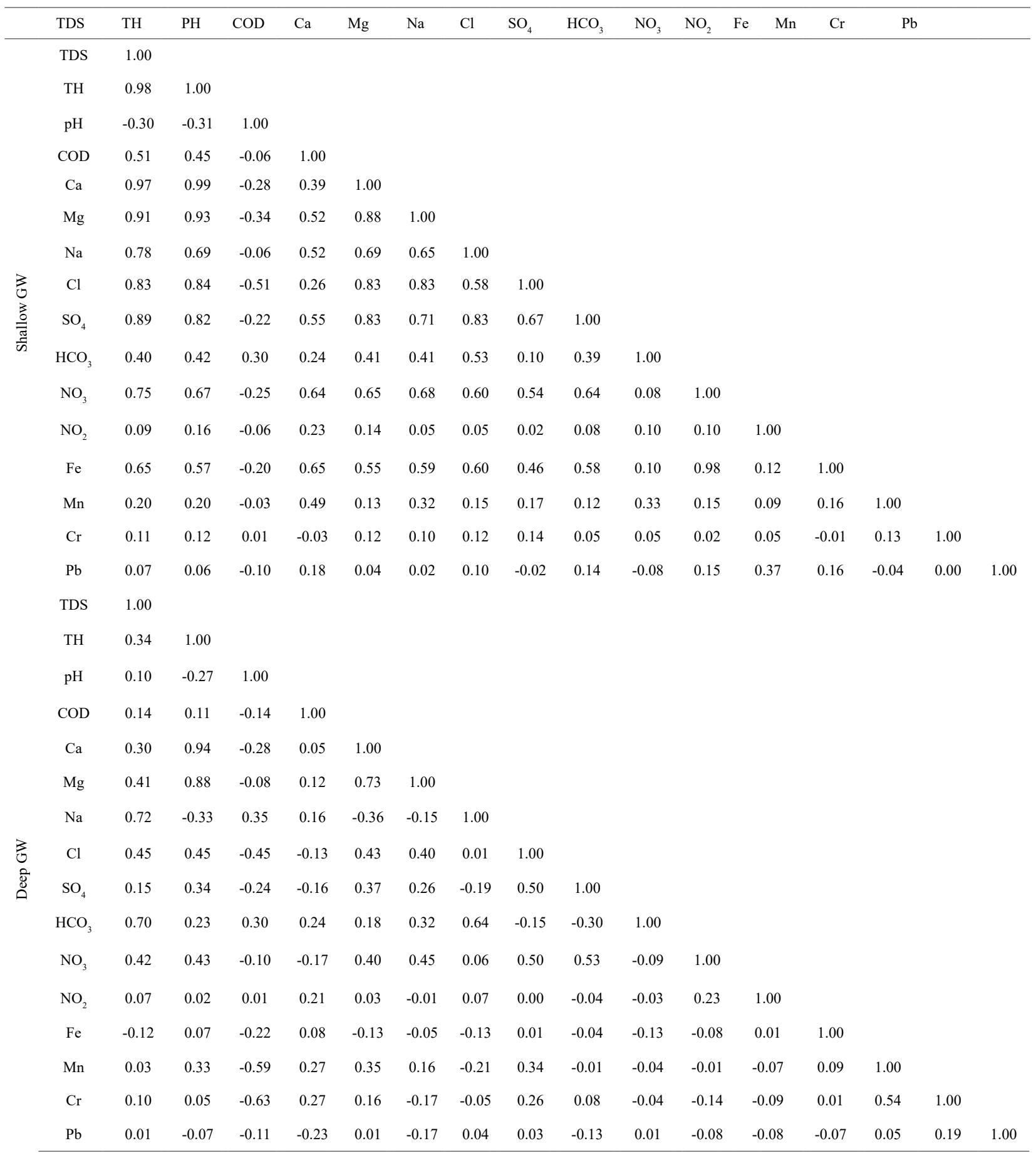

WATER QUALITY FOR DRINKING PURPOSE

The results of groundwater WQI in Hailun area are shown in Figure 5 (Tables 6 \& 8). As shown in Figure 5 , among the 77 shallow groundwater samples, 18 were 'excellent' (grade 1), 18 were 'good' (grade 2), 25 was 'poor' (grade 3), 10 were 'very poor' (grade 4), and
6 were 'unsuitable' (grade 5), accounting for 23.37, 23.37, 32.46, 12.98, and 7.79\%, respectively. Similarly, for 57 deep groundwater samples, 35 were 'excellent' (grade 1), 17 were 'good' (grade 2), 3 was 'poor' (grade 3), 1 was 'very poor' (grade 4), and 1 was 'unsuitable' (grade 5), accounting for $61.40,30.90,5.26,1.75$, and 
$1.75 \%$, respectively. The quality of deep groundwater is significantly better than that of shallow groundwater. The calculation results of WQI show that the deep groundwater in the study area is excellent for drinking purpose, while the shallow groundwater in some places is not suitable for drinking (Solangi et al. 2019).

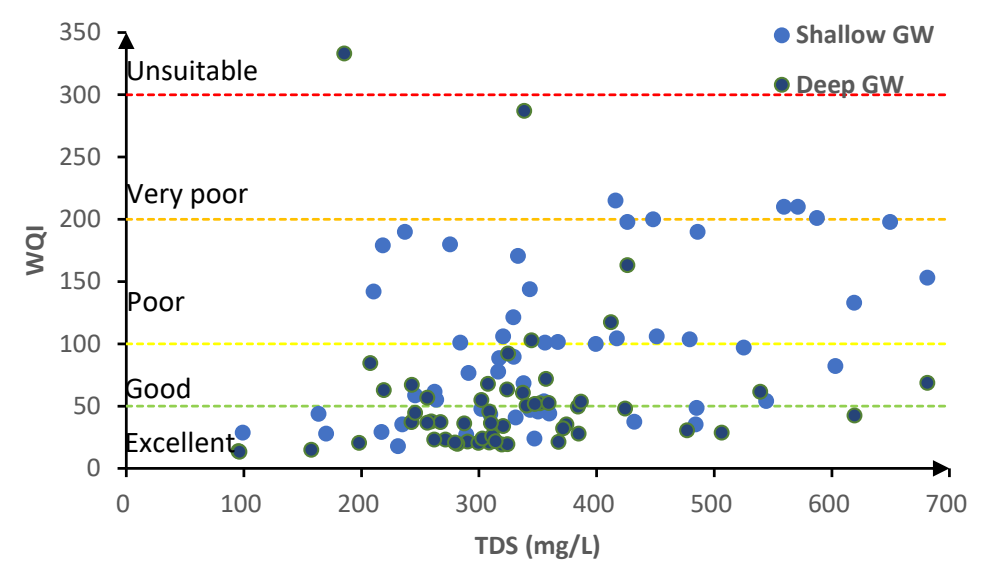

FIGURE 5. The diagram of Groundwater TDS versus WQI

The results of groundwater SPI in Hailun area are shown in Figure 6 (Tables 7 \& 9). As shown in Figure 6, among the 77 groundwater samples, 31 were 'suitable' (grade 1), 24 were 'slightly polluted' (grade 2), 6 were 'moderately polluted' (grade 3), 12 were 'highly polluted' (grade 4), and 4 were 'unsuitable' (grade 5), accounting for $40.25,31.16,7.79,15.58$, and $5.19 \%$, respectively.
Similarly, for 57 deep groundwater samples, 53 were 'suitable' (grade 1), and 4 were 'slightly polluted' (grade 2 ), accounting for 92.98 , and $7.02 \%$, respectively. The calculation results of SPI show that the deep groundwater in the study area is suitable for drinking, while the shallow groundwater in some places is unsuitable (Eslami et al. 2017).

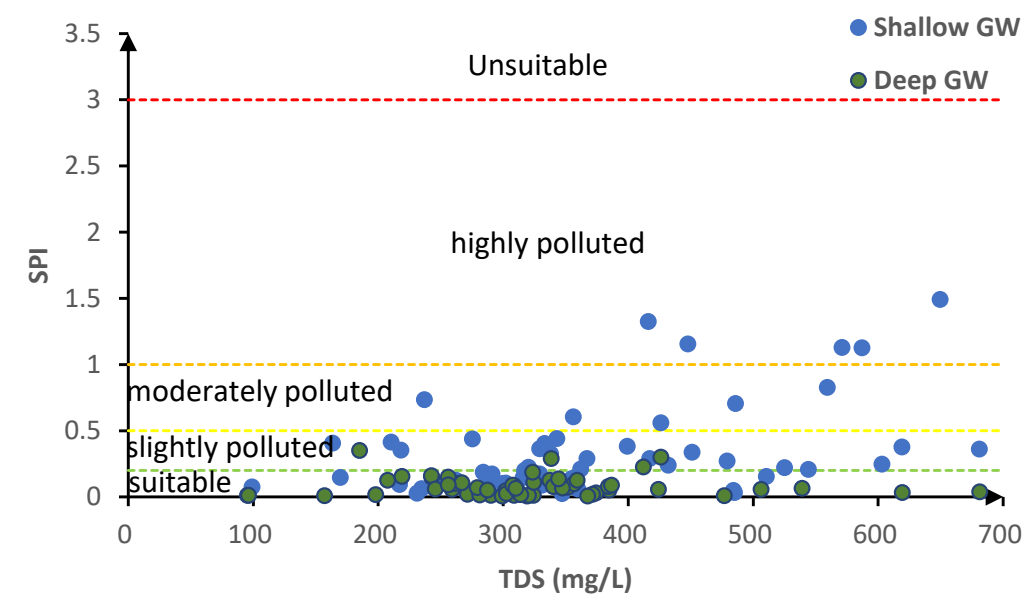

FIGURE 6. The diagram of Groundwater TDS versus SPI 


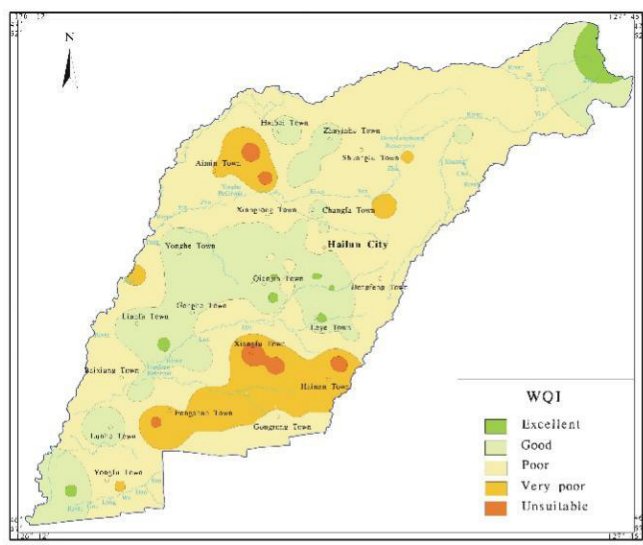

(a)

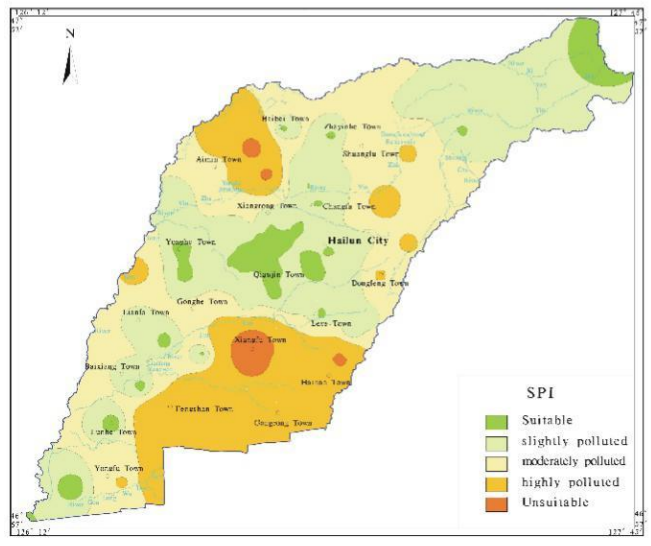

(c)

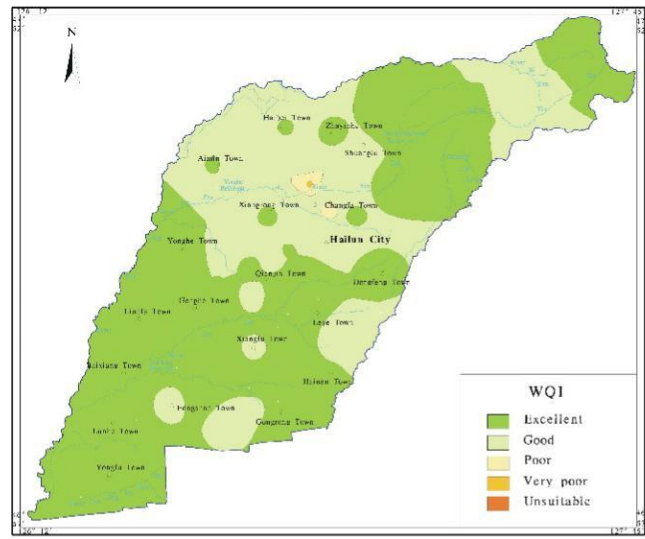

(b)

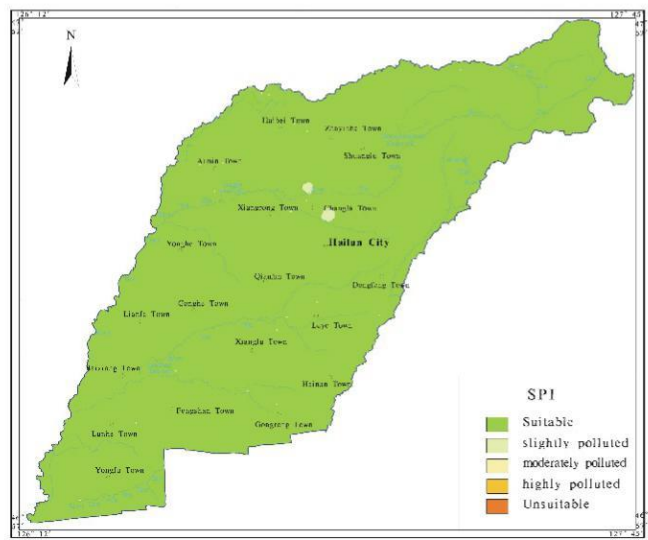

(d)

FIGURE 7. Spatial distribution groundwater quality maps based on the outcomes of the WQI model and SPI model

Based on the evaluation results of the water quality index model, the drinking water quality evaluation map of the study area was drawn (Figure 7). The spatial distribution of the water quality index shows that most of the deep groundwater index concentration ranges in the study area are below the WHO guidelines and are therefore suitable for drinking (Figure 7(b)). It is worth noting that in the southwest of the study area, the WQI index of shallow groundwater in small areas was found to be higher than 200 (Figure 7(a)). The WQI index exceeded the standard, mainly due to the extremely high concentration of $\mathrm{Fe}$ and $\mathrm{Mn}$ in groundwater. The high concentrations of $\mathrm{Fe}$ and $\mathrm{Mn}$ are not only affected by high concentrations in the Cretaceous aquifer, but also affected by human agricultural production (Adhikary et al. 2011). Therefore, the centralized water supply wells in this area should be added with $\mathrm{Fe}$ and $\mathrm{Mn}$ purification devices before drinking. Overall, it was learned from this study that the quality of groundwater complies with drinking water specifications according to $\mathrm{WHO}$ guidelines.

Based on the evaluation results of the SPI model, the drinking water quality evaluation map of the study area was drawn (Figure 7). The spatial distribution of the SPI shows that the deep groundwater indicators in most areas of the study area do not exceed the WHO guidelines, but there are signs of shallow groundwater pollution in some places (Figure 7(d)). Similar to the WQI spatial distribution results, in the north and southwest of the study area, the SPI index of shallow groundwater in small areas was found to be higher than 1.00. The SPI index exceeds 1.0, indicating that there is a high risk of contamination of groundwater in these areas, mainly due to the extremely high content of $\mathrm{Pb}$ in groundwater. The high concentration of $\mathrm{Pb}$ is mainly due to the impact of 
human activities (Dong et al. 2009). In this area, there are small-scale landfills, and the leakage of landfill leachate contaminates shallow groundwater, leading to an increase in $\mathrm{Pb}$ concentration. Therefore, in order to prevent serious pollution of groundwater, the leakproof layer of the landfill should be reinforced.

THE RELATIONSHIP BETWEEN WQI AND SPI MODELS

The relationship between the WQI and SPI models is established, and the water categories indicated by the two models are correlated through regression analysis, Equations (8) and (9). The relationship indicates a good correlation between WQI and SPI models $\left(\mathrm{R}^{2}=0.701, \mathrm{R}^{2}\right.$ $=0.7322$ ).

$$
\begin{aligned}
& \mathrm{SPI}_{\text {Shallow }}=0.0111 \times \mathrm{WQI}_{\text {Shallow }}-0.7223 \\
& \mathrm{SPI}_{\text {Deep }}=0.0012 \times \mathrm{WQI}_{\text {Deep }}+0.0173
\end{aligned}
$$

The WQI and SPI models provide efficient methods for valuable information about the overall quality of shallow groundwater and deep groundwater. Therefore, according to this study, it can be concluded that proper treatment of shallow groundwater in the study area is vital to the health of residents in the area.

\begin{tabular}{|c|c|c|c|c|c|c|c|c|}
\hline NO. & WQI & Rank & NO. & WQI & Rank & NO. & WQI & Rank \\
\hline 1 & 37.50 & Excellent & 27 & 101.07 & Poor & 53 & 43.44 & Excellent \\
\hline 2 & 54.13 & Good & 28 & 96.62 & Good & 54 & 206.00 & Very poor \\
\hline 3 & 29.21 & Excellent & 29 & 35.42 & Excellent & 55 & 48.48 & Excellent \\
\hline 4 & 133.66 & Poor & 30 & 53.85 & Good & 56 & 325.00 & Unsuitable \\
\hline 5 & 82.16 & Good & 31 & 180.00 & Poor & 57 & 44.07 & Excellent \\
\hline 6 & 27.07 & Excellent & 32 & 61.57 & Good & 58 & 68.54 & Good \\
\hline 7 & 101.41 & Poor & 33 & 198.00 & Poor & 59 & 144.00 & Poor \\
\hline 8 & 85.22 & Good & 34 & 100.00 & Poor & 60 & 35.33 & Excellent \\
\hline 9 & 97.03 & Good & 35 & 170.72 & Poor & 61 & 47.07 & Excellent \\
\hline 10 & 198.00 & Poor & 36 & 28.73 & Excellent & 62 & 387.00 & Unsuitable \\
\hline 11 & 133.00 & Poor & 37 & 89.60 & Good & 63 & 210.00 & Very poor \\
\hline 12 & 41.00 & Excellent & 38 & 210.00 & Very poor & 64 & 106.09 & Poor \\
\hline 13 & 103.75 & Poor & 39 & 190.00 & Poor & 65 & 398.00 & Unsuitable \\
\hline 14 & 62.90 & Good & 40 & 250.00 & Very poor & 66 & 198.00 & Poor \\
\hline 15 & 121.38 & Poor & 41 & 190.00 & Poor & 67 & 255.00 & Very poor \\
\hline 16 & 77.84 & Good & 42 & 200.00 & Very poor & 68 & 245.00 & Very poor \\
\hline 17 & 105.92 & Poor & 43 & 180.00 & Poor & 69 & 47.85 & Excellent \\
\hline 18 & 104.44 & Poor & 44 & 201.00 & Very poor & 70 & 399.00 & Unsuitable \\
\hline 19 & 17.87 & Excellent & 45 & 142.00 & Poor & 71 & 345.00 & Unsuitable \\
\hline 20 & 153.04 & Poor & 46 & 389.00 & Unsuitable & 72 & 58.88 & Good \\
\hline 21 & 24.04 & Excellent & 47 & 215.00 & Very poor & 73 & 49.01 & Excellent \\
\hline 22 & 100.99 & Poor & 48 & 58.55 & Good & 74 & 240.00 & Very poor \\
\hline 23 & 123.26 & Poor & 49 & 55.33 & Good & 75 & 145.27 & Poor \\
\hline 24 & 76.75 & Good & 50 & 43.94 & Excellent & 76 & 63.51 & Good \\
\hline 25 & 45.59 & Excellent & 51 & 179.00 & Poor & 77 & 70.88 & Good \\
\hline 26 & 88.53 & Good & 52 & 27.90 & Excellent & & & \\
\hline
\end{tabular}

TABLE 6. Categories of shallow groundwater based on the WQI model results 
TABLE 7. Categories of shallow groundwater based on the SPI model results

\begin{tabular}{|c|c|c|c|c|c|c|c|c|}
\hline NO. & SPI & Rank & NO. & SPI & Rank & NO. & SPI & Rank \\
\hline 1 & 0.24 & $\mathrm{SP}^{*}$ & 27 & 0.61 & MP* & 53 & 0.06 & $\mathrm{~S}^{*}$ \\
\hline 2 & 0.21 & $\mathrm{SP}^{*}$ & 28 & 0.14 & $\mathrm{~S}^{*}$ & 54 & 1.02 & $\mathrm{HP}^{*}$ \\
\hline 3 & 0.09 & $\mathrm{~S}^{*}$ & 29 & 0.05 & $\mathrm{~S}^{*}$ & 55 & 0.03 & $\mathrm{~S}^{*}$ \\
\hline 4 & 0.29 & $\mathrm{SP}^{*}$ & 30 & 0.14 & $\mathrm{~S}^{*}$ & 56 & 2.55 & HP* \\
\hline 5 & 0.25 & $\mathrm{SP}^{*}$ & 31 & 0.44 & $\mathrm{SP}^{*}$ & 57 & 0.06 & $\mathrm{~S}^{*}$ \\
\hline 6 & 0.10 & $\mathrm{~S}^{*}$ & 32 & 0.12 & $\mathrm{~S}^{*}$ & 58 & 0.33 & $\mathrm{SP}^{*}$ \\
\hline 7 & 0.29 & $\mathrm{SP}^{*}$ & 33 & 0.95 & MP* & 59 & 0.44 & $\mathrm{SP} *$ \\
\hline 8 & 0.09 & $\mathrm{~S}^{*}$ & 34 & 0.38 & $\mathrm{SP}^{*}$ & 60 & 0.06 & $\mathrm{~S}^{*}$ \\
\hline 9 & 0.22 & $\mathrm{SP}^{*}$ & 35 & 0.40 & $\mathrm{SP}^{*}$ & 61 & 0.08 & $\mathrm{~S}^{*}$ \\
\hline 10 & 0.56 & MP* & 36 & 0.08 & $\mathrm{~S}^{*}$ & 62 & 4.24 & $\mathrm{U}^{*}$ \\
\hline 11 & 0.38 & $\mathrm{SP}^{*}$ & 37 & 0.17 & $\mathrm{~S}^{*}$ & 63 & 0.83 & MP* \\
\hline 12 & 0.09 & $\mathrm{~S}^{*}$ & 38 & 1.13 & $\mathrm{HP}^{*}$ & 64 & 0.22 & $\mathrm{SP}^{*}$ \\
\hline 13 & 0.27 & SP* & 39 & 0.71 & MP* & 65 & 4.01 & $\mathrm{U}^{*}$ \\
\hline 14 & 0.04 & $\mathrm{~S}^{*}$ & 40 & 1.74 & $\mathrm{HP}^{*}$ & 66 & 1.49 & $\mathrm{HP}^{*}$ \\
\hline 15 & 0.36 & SP* & 41 & 0.74 & MP* & 67 & 2.15 & HP* \\
\hline 16 & 0.15 & $\mathrm{~S}^{*}$ & 42 & 1.16 & HP* & 68 & 2.14 & HP* \\
\hline 17 & 0.34 & $\mathrm{SP}^{*}$ & 43 & 0.44 & $\mathrm{SP}^{*}$ & 69 & 0.11 & $\mathrm{~S}^{*}$ \\
\hline 18 & 0.29 & SP* & 44 & 1.13 & HP* & 70 & 8.55 & $\mathrm{U}^{*}$ \\
\hline 19 & 0.03 & $\mathrm{~S}^{*}$ & 45 & 0.42 & $\mathrm{SP}^{*}$ & 71 & 2.72 & $\mathrm{HP}^{*}$ \\
\hline 20 & 0.36 & SP* & 46 & 3.82 & $\mathrm{U}^{*}$ & 72 & 0.10 & $\mathrm{~S}^{*}$ \\
\hline 21 & 0.03 & $\mathrm{~S}^{*}$ & 47 & 1.32 & HP* & 73 & 0.10 & $\mathrm{~S}^{*}$ \\
\hline 22 & 0.19 & $\mathrm{~S}^{*}$ & 48 & 0.09 & $\mathrm{~S}^{*}$ & 74 & 1.30 & $\mathrm{HP}^{*}$ \\
\hline 23 & 0.19 & $\mathrm{~S}^{*}$ & 49 & 0.08 & $\mathrm{~S}^{*}$ & 75 & 0.15 & $\mathrm{~S}^{*}$ \\
\hline 24 & 0.17 & $\mathrm{~S}^{*}$ & 50 & 0.41 & $\mathrm{SP}^{*}$ & 76 & 0.19 & $\mathrm{~S}^{*}$ \\
\hline 25 & 0.10 & $\mathrm{~S}^{*}$ & 51 & 0.35 & $\mathrm{SP}^{*}$ & 77 & 0.21 & $\mathrm{SP}^{*}$ \\
\hline 26 & 0.20 & SP* & 52 & 0.15 & $\mathrm{~S}^{*}$ & & & \\
\hline
\end{tabular}

$\mathrm{S}^{*}=$ suitable, $\mathrm{SP}^{*}=$ slightly polluted, MP* =moderately polluted, HP* =highly polluted, US* =unsuitable

TABLE 8. Categories of deep groundwater based on the WQI model results

\begin{tabular}{ccccccccc}
\hline NO. & WQI & Rank & NO. & WQI & Rank & NO. & WQI & Rank \\
\hline 1 & 28.04 & Excellent & 20 & 21.35 & Excellent & 39 & 44.71 & Excellent \\
2 & 30.47 & Excellent & 21 & 34.12 & Excellent & 40 & 84.60 & Good \\
3 & 28.77 & Excellent & 22 & 67.13 & Good & 41 & 92.25 & Good \\
4 & 61.46 & Good & 23 & 20.46 & Excellent & 42 & 50.45 & Good \\
5 & 21.48 & Excellent & 24 & 23.96 & Excellent & 43 & 51.88 & Good
\end{tabular}




\begin{tabular}{lcccccccc}
6 & 60.70 & Good & 25 & 20.56 & Excellent & 44 & 13.79 & Excellent \\
7 & 42.46 & Excellent & 26 & 333.29 & Unsuitable & 45 & 13.49 & Excellent \\
8 & 45.70 & Excellent & 27 & 287.05 & Very poor & 46 & 36.43 & Excellent \\
9 & 35.30 & Excellent & 28 & 37.84 & Excellent & 47 & 21.85 & Excellent \\
10 & 49.52 & Excellent & 29 & 37.17 & Excellent & 48 & 102.99 & Poor \\
11 & 54.90 & Good & 30 & 15.05 & Excellent & 49 & 63.51 & Good \\
12 & 23.08 & Excellent & 31 & 48.00 & Excellent & 50 & 117.39 & Poor \\
13 & 19.10 & Excellent & 32 & 52.29 & Good & 51 & 163.32 & Poor \\
14 & 19.72 & Excellent & 33 & 68.71 & Good & 52 & 56.86 & Good \\
15 & 19.58 & Excellent & 34 & 26.14 & Excellent & 53 & 36.34 & Excellent \\
16 & 20.73 & Excellent & 35 & 53.63 & Good & 54 & 52.44 & Good \\
17 & 36.08 & Excellent & 36 & 23.22 & Excellent & 55 & 37.24 & Excellent \\
18 & 32.06 & Excellent & 37 & 67.95 & Good & 56 & 36.74 & Excellent \\
19 & 20.91 & Excellent & 38 & 71.86 & Good & 57 & 62.98 & Good \\
\hline
\end{tabular}

TABLE 9. Categories of deep groundwater based on the SPI model results

\begin{tabular}{|c|c|c|c|c|c|c|c|c|}
\hline NO. & SPI & Rank & NO. & SPI & Rank & NO. & SPI & Rank \\
\hline 1 & 0.05 & $\mathrm{~S}^{*}$ & 20 & 0.01 & $\mathrm{~S}^{*}$ & 39 & 0.06 & $\mathrm{~S}^{*}$ \\
\hline 2 & 0.01 & $S^{*}$ & 21 & 0.01 & $\mathrm{~S}^{*}$ & 40 & 0.13 & $\mathrm{~S}^{*}$ \\
\hline 3 & 0.06 & $S^{*}$ & 22 & 0.15 & $\mathrm{~S}^{*}$ & 41 & 0.11 & $S^{*}$ \\
\hline 4 & 0.06 & $\mathrm{~S}^{*}$ & 23 & 0.01 & $\mathrm{~S}^{*}$ & 42 & 0.08 & $\mathrm{~S}^{*}$ \\
\hline 5 & 0.01 & $\mathrm{~S}^{*}$ & 24 & 0.02 & $\mathrm{~S}^{*}$ & 43 & 0.07 & $\mathrm{~S}^{*}$ \\
\hline 6 & 0.13 & $\mathrm{~S}^{*}$ & 25 & 0.02 & $\mathrm{~S}^{*}$ & 44 & 0.01 & $\mathrm{~S}^{*}$ \\
\hline 7 & 0.03 & $\mathrm{~S}^{*}$ & 26 & 0.35 & $\mathrm{SP} *$ & 45 & 0.01 & $\mathrm{~S}^{*}$ \\
\hline 8 & 0.08 & $\mathrm{~S}^{*}$ & 27 & 0.29 & SP* & 46 & 0.05 & $S^{*}$ \\
\hline 9 & 0.03 & $\mathrm{~S}^{*}$ & 28 & 0.06 & $\mathrm{~S}^{*}$ & 47 & 0.02 & $\mathrm{~S}^{*}$ \\
\hline 10 & 0.08 & $\mathrm{~S}^{*}$ & 29 & 0.16 & $\mathrm{~S}^{*}$ & 48 & 0.14 & $\mathrm{~S}^{*}$ \\
\hline 11 & 0.05 & $\mathrm{~S}^{*}$ & 30 & 0.01 & $\mathrm{~S}^{*}$ & 49 & 0.19 & $\mathrm{~S}^{*}$ \\
\hline 12 & 0.02 & $\mathrm{~S}^{*}$ & 31 & 0.06 & $\mathrm{~S}^{*}$ & 50 & 0.23 & $\mathrm{SP}^{*}$ \\
\hline 13 & 0.01 & $\mathrm{~S}^{*}$ & 32 & 0.07 & $\mathrm{~S}^{*}$ & 51 & 0.30 & $\mathrm{SP}^{*}$ \\
\hline 14 & 0.01 & $\mathrm{~S}^{*}$ & 33 & 0.04 & $\mathrm{~S}^{*}$ & 52 & 0.15 & $\mathrm{~S}^{*}$ \\
\hline 15 & 0.01 & $\mathrm{~S}^{*}$ & 34 & 0.05 & $\mathrm{~S}^{*}$ & 53 & 0.06 & $\mathrm{~S}^{*}$ \\
\hline 16 & 0.07 & $\mathrm{~S}^{*}$ & 35 & 0.09 & $\mathrm{~S}^{*}$ & 54 & 0.13 & $\mathrm{~S}^{*}$ \\
\hline 17 & 0.05 & $\mathrm{~S}^{*}$ & 36 & 0.10 & $\mathrm{~S}^{*}$ & 55 & 0.11 & $\mathrm{~S}^{*}$ \\
\hline 18 & 0.02 & $\mathrm{~S}^{*}$ & 37 & 0.09 & $\mathrm{~S}^{*}$ & 56 & 0.09 & $\mathrm{~S}^{*}$ \\
\hline 19 & 0.01 & $\mathrm{~S}^{*}$ & 38 & 0.10 & $\mathrm{~S}^{*}$ & 57 & 0.15 & $\mathrm{~S}^{*}$ \\
\hline
\end{tabular}

$\mathrm{S}^{*}=$ suitable, $\mathrm{SP} *=$ slightly polluted, $\mathrm{MP} *=$ moderately polluted, $\mathrm{HP} *$ =highly polluted, $\mathrm{US} *$ =unsuitable 


\section{CONCLUSION}

This study explored the factors affecting groundwater chemistry and its quality in detail, and analyzed the hydrogeological processes of shallow groundwater and deep groundwater. In accordance with WHO (2008) guidance, groundwater quality assessments have also been introduced to assess suitability for drinking. The following three conclusions are concluded: First, deep groundwater in aquifers in the study area is weakly alkaline, while that of shallow groundwater is weakly acidic. The abundance for both deep groundwater and shallow groundwater are in the order $\mathrm{HCO}_{3}{ }^{-}>\mathrm{Cl}^{-}>\mathrm{SO}_{4}{ }^{2-}$ for anions, and $\mathrm{Ca}^{2+}>\mathrm{Na}^{+}>\mathrm{Mg}^{2+}$ for cations, resulting that the water types were dominated by $\mathrm{HCO}_{3}-\mathrm{Ca}, \mathrm{HCO}_{3}-\mathrm{Ca} \bullet \mathrm{Mg}$, and $\mathrm{HCO}_{3}-\mathrm{Ca} \cdot \mathrm{Na}$ types. Second, $\mathrm{CA}$ and Durov diagram show that rock weathering and dissolution, human activities, and the hydraulic connection between shallow and deep water are the main reasons affecting the chemical composition of water in Helen. At the same time, the high scores of $\mathrm{Pb}, \mathrm{NO}_{2}^{-}, \mathrm{Fe}$, and $\mathrm{Mn}$ must be widely concerned and may become the main environmental geological problems in the area. Third, the analysis of water samples based on the WQI model showed that about 23.37, 23.37, $32.46,12.98$, and $7.79 \%$ of the shallow groundwater samples were excellent, good, poor, very poor, and unsuitable for drinking purposes, and that 61.40, 30.90, $5.26,1.75$, and $1.75 \%$ of the deep groundwater samples were excellent, good, poor, very poor, and unsuitable for drinking purposes, respectively. The analysis of groundwater samples based on the SPI model showed that $92.98 \%$ of the deep groundwater samples were suitable grade, while that $40.25 \%$ of the shallow groundwater samples were suitable grade. The spatial distribution maps of the water quality index and the SPI show that most of the deep groundwater resources in the study area are clean and suitable for drinking, despite the risks of the shallow groundwater in the north and southwest of the study area.

\section{ACKNOWLEDGEMENTS}

This work was supported by the projects of hydrological and geological survey in Hailun, Bayan and Wuhe Area (Item Number: DD20190340-1). We would also like to thank Yonggen Zhang, Shanghai Du, Zhuang Kang and Xiaoqing Sun for helping us with mapping and writing skills in the process of writing this paper. We are also grateful to the valuable comments and suggestions given by the editors and the anonymous reviewers.

\section{REFERENCES}

Abbasnia, A., Yousefi, N., Mahvi, A.H., Nabizadeh, R., Radfard, M., Yousefi, M. \& Alimohammadi, M. 2019. Evaluation of groundwater quality using water quality index and its suitability for assessing water for drinking and irrigation purposes: Case study of Sistan and Baluchistan province
(Iran). Human and Ecological Risk Assessment: An International Journal 25(4): 988-1005.

Abbasnia, A., Alimohammadi, M., Mahvi, A.H., Nabizadeh, R., Yousefi, M., Mohammadi, A.A. \& Mirzabeigi, M. 2018. Assessment of groundwater quality and evaluation of scaling and corrosiveness potential of drinking water samples in villages of Chabahr city, Sistan and Baluchistan province in Iran. Data in Brief 16: 182-192.

Adhikary, P.P., Dash, C.J., Bej, R. \& Chandrasekharan, H. 2011. Indicator and probability kriging methods for delineating $\mathrm{Cu}, \mathrm{Fe}$, and $\mathrm{Mn}$ contamination in groundwater of Najafgarh Block, Delhi, India. Environmental Monitoring and Assessment 176(1-4): 663-676.

Boyd, C.E. 2019. Water Quality: An Introduction. Singapore: Springer Nature.

Brhane, G.K. 2018. Characterization of hydro chemistry and groundwater quality evaluation for drinking purpose in Adigrat area, Tigray, Northern Ethiopia. Water Science 32(2): 213-229.

Chen, P., Nie, T., Chen, S., Zhang, Z., Qi, Z. \& Liu, W. 2019a. Recovery efficiency and loss of $15 \mathrm{~N}$-labelled urea in a ricesoil system under water saving irrigation in the Songnen Plain of Northeast China. Agricultural Water Management 222: 139-153.

Chen, J., Zhu, R., Zhang, Q., Kong, X. \& Sun, D. 2019 b. Reduced-tillage management enhances soil properties and crop yields in a alfalfa-corn rotation: Case study of the Songnen Plain, China. Scientific Reports 9(1): 1-10.

Dippong, T., Mihali, C., Hoaghia, M.A., Cical, E. \& Cosma, A. 2019. Chemical modeling of groundwater quality in the aquifer of Seini town-Someș Plain, Northwestern Romania. Ecotoxicology and Environmental Safety 168: 88-101.

Dong, D., Zhao, X., Hua, X., Liu, J. \& Gao, M. 2009. Investigation of the potential mobility of $\mathrm{Pb}, \mathrm{Cd}$ and $\mathrm{Cr}$ (VI) from moderately contaminated farmland soil to groundwater in Northeast, China. Journal of Hazardous Materials 162(2-3): 1261-1268.

Eslami, F., Shokoohi, R., Mazloomi, S., Darvish Motevalli, M. \& Salari, M. 2017. Evaluation of water quality index (WQI) of groundwater supplies in Kerman Province in 2015. Occupational and Environmental Health 3(1): 48-58.

Gastmans, D., Mira, A., Kirchheim, R., Vives, L., Rodríguez, L. \& Veroslavsky, G. 2017. Hypothesis of groundwater flow through geological structures in Guarani Aquifer System (GAS) using chemical and isotopic data. Procedia Earth and Planetary Science 17: 136-139.

Gautam, S.K., Maharana, C., Sharma, D., Singh, A.K., Tripathi, J.K. \& Singh, S.K. 2015. Evaluation of groundwater quality in the Chotanagpur plateau region of the Subarnarekha river basin, Jharkhand State, India. Sustainability of Water Quality and Ecology 6: 57-74.

Hasan, M., Shang, Y., Akhter, G. \& Jin, W. 2017. Evaluation of groundwater suitability for drinking and irrigation purposes in Toba Tek Singh District, Pakistan. Irrig. Drain. Syst. Eng. 6: 185.

Hausladen, D.M., Alexander-Ozinskas, A., McClain, C. \& Fendorf, S. 2018. Hexavalent chromium sources and distribution in California groundwater. Environmental Science \& Technology 52(15): 8242-8251. 
Karunanidhi, D., Aravinthasamy, P., Subramani, T., Roy, P.D. \& Srinivasamoorthy, K. 2020. Risk of fluoride-rich groundwater on human health: Remediation through managed aquifer recharge in a hard rock terrain, South India. Natural Resources Research 29: 2369-2395.

Khan, R. \& Jhariya, D.C. 2017. Groundwater quality assessment for drinking purpose in Raipur City, Chhattisgarh using water quality index and geographic information system. Journal of the Geological Society of India 90(1): 69-76.

Kumar, S.K., Babu, S.H., Rao, P.E., Selvakumar, S., Thivya, C., Muralidharan, S. \& Jeyabal, G. 2017. Evaluation of water quality and hydrogeochemistry of surface and groundwater, Tiruvallur District, Tamil Nadu, India. Applied Water Science 7(5): 2533-2544.

Li, B., Huang, F., Qin, L., Qi, H. \& Sun, N. 2019. Spatio-temporal variations of carbon use efficiency in natural terrestrial ecosystems and the relationship with climatic factors in the Songnen Plain, China. Remote Sensing 11(21): 2513.

Li, M., Han, X., Du, S. \& Li, L.J. 2019. Profile stock of soil organic carbon and distribution in croplands of Northeast China. Catena 174: 285-292.

Li, Y., Zhang, Q., Lu, J., Yao, J. \& Tan, Z. 2019. Assessing surface water-groundwater interactions in a complex riverfloodplain wetland-isolated lake system. River Research and Applications 35(1): 25-36.

Madlala, T., Kanyerere, T., Oberholster, P. \& Xu, Y. 2019. Application of multi-method approach to assess groundwatersurface water interactions, for catchment management. International Journal of Environmental Science and Technology 16(5): 2215-2230.

Misaghi, F., Delgosha, F., Razzaghmanesh, M. \& Myers, B. 2017. Introducing a water quality index for assessing water for irrigation purposes: A case study of the Ghezel Ozan River. Science of The Total Environment 589: 107-116.

Niu, S., Gao, L. \& Wang, X. 2019. Characterization of contamination levels of heavy metals in agricultural soils using geochemical baseline concentrations. Journal of Soils and Sediments 19(4): 1697-1707.

Ravikumar, P. \& Somashekar, R.K. 2017. Principal component analysis and hydrochemical facies characterization to evaluate groundwater quality in Varahi river basin, Karnataka state, India. Applied Water Science 7(2): 745-755.

Ravindra, K. \& Mor, S. 2019. Distribution and health risk assessment of arsenic and selected heavy metals in Groundwater of Chandigarh, India. Environmental Pollution 250: $820-830$.

Rotiroti, M., Bonomi, T. \& Fumagalli, L. 2013. An integrated approach to assess origin and mobilization of As, Fe and $\mathrm{Mn}$ in groundwater: The case study of Cremona (Northern Italy). EGU General Assembly Conference Abstracts.

Şener, Ş., Şener, E. \& Davraz, A. 2017. Evaluation of water quality using water quality index (WQI) method and GIS in Aksu River (SW-Turkey). Science of The Total Environment 584: 131-144.

Solangi, G.S., Siyal, A.A., Babar, M.M. \& Siyal, P. 2019. Evaluation of drinking water quality using the water quality index (WQI), the synthetic pollution index (SPI) and geospatial tools in Thatta district, Pakistan. Desalination and Water Treatment 160: 202-213.
Solangi, G.S., Siyal, A.A., Babar, M.M. \& Siyal, P. 2018. Evaluation of surface water quality using the water quality index (WQI) and the synthetic pollution index (SPI): A case study of Indus Delta region of Pakistan. Desalination and Water Treatment 118: 39-48.

Soleimani, H., Nasri, O., Ojaghi, B., Pasalari, H., Hosseini, M., Hashemzadeh, B. \& Feizabadi, G.K. 2018. Data on drinking water quality using water quality index (WQI) and assessment of groundwater quality for irrigation purposes in Qorveh\&Dehgolan, Kurdistan, Iran. Data in Brief 20: 375-386.

Sun, Y., Xu, S.G., Kang, P.P., Fu, Y.Z. \& Wang, T.X. 2019. Impacts of artificial underground reservoir on groundwater environment in the reservoir and downstream area. International Journal of Environmental Research and Public Health 16(11): 1921.

Tian, H., Liang, X., Gong, Y., Qi, L., Liu, Q., Kang, Z. \& Jin, H. 2020a. Health risk assessment of nitrate pollution in shallow groundwater: A case study in China. Pol. J. Environ. Stud. 29(1): 827-839.

Tian, H., Liang, X., Gong, Y., Ma, S., Kang, Z., Sun, Q. \& Jin, H. 2020b. Risk assessment of metals from shallow groundwater in Lianhuashan District, China. La Houille Blanche (1): 5-15.

Tian, H., Liang, X., Gong, Y., Kang, Z. \& Jin, H. 2019. Health risk assessment of nitrate pollution in shallow groundwater: A case study in Changchun New District, China. La Houille Blanche (5-6): 45-58.

Van Dijk, G., Wolters, J., Fritz, C., De Mars, H., Van Duinen, G.J., Ettwig, K.F. \& Smolders, A.J.P. 2019. Effects of groundwater nitrate and sulphate enrichment on groundwaterfed mires: A case study. Water, Air, \& Soil Pollution 230(6): 122.

Wagh, V.M., Mukate, S.V., Panaskar, D.B., Muley, A.A. \& Sahu, U.L. 2019. Study of groundwater hydrochemistry and drinking suitability through Water Quality Index (WQI) modelling in Kadava river basin, India. SN Applied Sciences 1(10): 1251.

Wooding, M., Rohwer, E.R. \& Naudé, Y. 2017. Determination of endocrine disrupting chemicals and antiretroviral compounds in surface water: A disposable sorptive sampler with comprehensive gas chromatography-time-of-flight mass spectrometry and large volume injection with ultrahigh performance liquid chromatography-tandem mass spectrometry. Journal of Chromatography A 1496: 122-132.

World Health Organization (WHO). 2008. Guidelines for Drinking-Water Quality. Geneva: World Health Organization.

Wu, H., Guan, Q., Ma, H., Xue, Z., Yang, M. \& Batzer, D.P. 2019. Effects of saline conditions and hydrologic permanence on snail assemblages in wetlands of Northeastern China. Ecological Indicators 96: 620-627.

Xing, Z., Tian, K., Du, C., Li, C., Zhou, J. \& Chen, Z. 2019. Agricultural soil characterization by FTIR spectroscopy at micrometer scales: Depth profiling by photoacoustic spectroscopy. Geoderma 335: 94-103.

Zhang, B., Song, X., Zhang, Y., Han, D., Tang, C., Yu, Y. \& Ma, Y. 2012. Hydrochemical characteristics and water quality assessment of surface water and groundwater in Songnen 
plain, Northeast China. Water Research 46(8): 2737-2748.

Zhao, H.Q., Zhang, Z.H. \& Chen, Y. 2010. Lowering of groundwater level and its negative environment effects in the Songnen Plain. Journal of Arid Land Resources and Environment 24(1): 126-130.

Zhou, M., Liu, X., Meng, Q., Zeng, X., Zhang, J., Li, D. \& Ma, X. 2019. Additional application of aluminum sulfate with different fertilizers ameliorates saline-sodic soil of Songnen Plain in Northeast China. Journal of Soils and Sediments 19(10): 3521-3533.

Zanotti, C., Rotiroti, M., Fumagalli, L., Stefania, G.A., Canonaco, F., Stefenelli, G. \& Bonomi, T. 2019. Groundwater and surface water quality characterization through positive matrix factorization combined with GIS approach. Water Research 159: 122-134.

Tian Hui*, Du Jizhong, Sun Qifa, Liu Qiang, Kang Zhuang \& Jin Hongtao

Shenyang Geological Survey Center

China Geological Survey

Shenyang 110034

China
Tian Hui*

Key Laboratory of Groundwater Resources and Environment Ministry of Education

Jilin University, Changchun 130021

China

Tian Hui*

College of New Energy and Environment

Jilin University, Changchun 130021

China

*Corresponding author; email: 359585977@qq.com

Received: 10 February 2020

Accepted: 13 April 2020 